\title{
Microbial synthesis of zinc oxide nanoparticles and their potential application as an antimicrobial agent and a feed supplement in animal industry: a review
}

Hidayat Mohd Yusof ${ }^{1}$, Rosfarizan Mohamad ${ }^{1,2}$, Uswatun Hasanah Zaidan ${ }^{3}$ and Nor' Aini Abdul Rahman ${ }^{1,2^{*}}$

\begin{abstract}
In recent years, zinc oxide nanoparticles (ZnO NPs) have gained tremendous attention attributed to their unique properties. Notably, evidence has shown that zinc is an important nutrient in living organisms. As such, both prokaryotes and eukaryotes including bacteria, fungi and yeast are exploited for the synthesis of ZnO NPs by using microbial cells or enzyme, protein and other biomolecules compounds in either an intracellular or extracellular route. ZnO NPs exhibit antimicrobial properties, however, the properties of nanoparticles (NPs) are depended upon on their size and shape, which make them specific for various applications. Nevertheless, the desired size and shape of NPs can be obtained through the optimization process of microbes mediated synthesis by manipulating their reaction conditions. It should be noted that ZnO NPs are synthesized by various chemical and physical methods. Nonetheless, these methods are expensive and not environmentally friendly. On that account, the microbes mediated synthesis of ZnO NPs have rapidly evolved recently where the microbes are cleaner, eco-friendly, nontoxic and biocompatible as the alternatives to chemical and physical practices. Moreover, zinc in the form of NPs is more effective than their bulk counterparts and thus, they have been explored for many potential applications including in animals industry. Notably, with the advent of multi-drug resistant strains, ZnO NPs have emerged as the potential antimicrobial agents. This is mainly due to their superior properties in combating a broad spectrum of pathogens. Moreover, zinc is known as an essential trace element for most of the biological function in the animal's body. As such, the applications of ZnO NPs have been reported to significantly enhance the health and production of the farm animals. Thus, this paper reviews the biological synthesis of ZnO NPs by the microbes, the mechanisms of the biological synthesis, parameters for the optimization process and their potential application as an antimicrobial agent and feed supplement in the animal industry as well as their toxicological hazards on animals.
\end{abstract}

Keywords: Animals, Antimicrobial, Feed supplement, Microbial synthesis, Nanotechnology, Zinc oxide nanoparticles

\footnotetext{
*Correspondence: nor_aini@upm.edu.my

'Department of Bioprocess Technology, Faculty of Biotechnology and Biomolecular Sciences, Universiti Putra Malaysia, 43400 Serdang, Selangor, Malaysia

${ }^{2}$ Bioprocessing and Biomanufacturing Research Centre, Faculty of Biotechnology and Biomolecular Sciences, Universiti Putra Malaysia, 43400 Serdang, Selangor, Malaysia

Full list of author information is available at the end of the article
}

(c) The Author(s). 2019 Open Access This article is distributed under the terms of the Creative Commons Attribution 4.0 International License (http://creativecommons.org/licenses/by/4.0/), which permits unrestricted use, distribution, and reproduction in any medium, provided you give appropriate credit to the original author(s) and the source, provide a link to the Creative Commons license, and indicate if changes were made. The Creative Commons Public Domain Dedication waiver (http://creativecommons.org/publicdomain/zero/1.0/) applies to the data made available in this article, unless otherwise stated. 


\section{Introduction}

Over the last decade, nanotechnology has emerged as a technology that has revolutionized every field of applied science. The field of nanoparticles (NPs) is one of the avenues to nanotechnology that is associated with nanoscale materials with very small particles size ranging from 1 to $100 \mathrm{~nm}$. NPs exhibit distinctive properties owing to their extremely small size and high surface area to volume ratio, which have attributed to the significant differences in the properties over their bulk counterparts [1]. In this regard, NPs have been integrated into various industries by providing innovative solutions.

There are various types of metal oxide including titanium dioxide $\left(\mathrm{TiO}_{2}\right)$, indium (III) oxide $\left(\mathrm{In}_{2} \mathrm{O}_{3}\right)$, zinc oxide $(\mathrm{ZnO})$, tin (IV) oxide $\left(\mathrm{SnO}_{2}\right)$ and silicon dioxide $\left(\mathrm{SiO}_{2}\right)$, where $\mathrm{ZnO}$ is one of the abundantly produced metal oxides after $\mathrm{SiO}_{2}$ and $\mathrm{TiO}_{2}$ [2]. $\mathrm{ZnO}$ is an inorganic material that exhibits unique properties including semiconductor, a wide range of radiation absorption, piezoelectric, pyroelectric and possesses high catalytic activity [3]. In addition, $\mathrm{ZnO}$ has been listed as "Generally Recognized as Safe" (GRAS) by the US Food and Drug Administration (FDA 21CFR182.8991) [4] due to its non-toxic properties [5]. Consequently, this makes it safe to be used on human and animals. In recent years, there has been increased interest in zinc oxide nanoparticles ( $\mathrm{ZnO} \mathrm{NPs}$ ). This is mainly due to their smallest particles size, which enhances their chemical reactivity. Consequently, this has extended the wide application of $\mathrm{ZnO}$ NPs in electronics, optics, biomedicine and agriculture [6-9].

Zinc are an important nutrient in living organisms [911]. Evidence has indicated that $\mathrm{ZnO}$ NPs have a great potential in biological applications, particularly as the antimicrobial agents [12,13]. Moreover, numerous studies have been reported on the efficiency of $\mathrm{ZnO}$ NPs in inhibiting the growth of broad-spectrum of pathogens [14-16], which potentially could replace the conventional antibiotic. Furthermore, zinc is an important trace mineral that plays a vital role in many physiological functions in the body $[9,11,17,18]$. As such, the integration of NPs in feed would increase the absorption and efficient use of zinc in the body, hence, result in improved health and productivity [19]. Moreover, evidence has indicated that $\mathrm{ZnO}$ NPs exhibit potential applications in the poultry and livestock industries, particularly as a feed supplement in the animal's diet [9]. Numerous studies have been carried out to verify the potential use of $\mathrm{ZnO}$ NPs as dietary supplement in improving the growth performances [20-22], increase in the bioavailability of zinc $[23,24]$, enhancing the immune response $[18,25,26]$, enhancing the antioxidative property [25, 27] and also improving the egg qualities and productions of layer chicken $[24,25,28]$. Nevertheless, to date, data on the use of $\mathrm{ZnO}$ NPs produced by microbial synthesis for the applications in animal feed has been scant.

Traditionally, ZnO NPs are synthesized using physical and chemical processes, which offer higher production rate and produce the better-controlled size of NPs. Nonetheless, these methods are considered unfavourable due to high capital cost, high energy requirements and involve the use of toxic and hazardous chemicals. Consequently, these features result in secondary pollution to the environment. Moreover, a previous study demonstrated that the chemical synthesis of NPs is toxic and less biocompatible [29]. Hence, this has limited their clinical and biomedical applications. Therefore, there is a need to explore and develop cleaner, environmentally safe, economical and biocompatible alternatives to synthesize NPs.

In recent years, the green process of NPs has emerged as an alternative to conventional physical and chemical methods by using biological mediated approaches. The biological synthesis of metal and metal oxide NPs involves unicellular and multicellular biological entities including bacteria [30], yeast [14], fungi [31], virus [32] and algae [33]. These methods are cheap, non-toxic and eco-friendly. The microbes act as a tiny nano-factory in reducing the metal ions into metal NPs with the involvement of enzymes and other biomolecule compounds secreted or produced by the microbes. Nevertheless, only a few microbes are reported to have the capability to synthesise $\mathrm{ZnO}$ NPs. Hence, there is a need to explore more potential microbes for the synthesis of $\mathrm{ZnO}$ NPs. Therefore, the current paper reviews the microbes mediated synthesis of $\mathrm{ZnO}$ NPs, the mechanisms of NPs synthesis and optimization parameters and their potential application as an antimicrobial agent and feed supplement in animal industry as well as their toxicological hazards on animal.

\section{Microbial mediated synthesis of $\mathrm{ZnO}$ NPs}

NPs have been synthesized by using various conventional physical and chemical methods such as vapour condensation, interferometric lithography, physical fragmentation, sol-gel process, solvent evaporation process and precipitation from microemulsion method [34, 35]. The physical method involves the use of high energy consumption, pressure and temperature, whereas, the chemical method involves the use of perilous and toxic chemicals which contributing in environmental contaminants and hazardous to the person handling it [36]. The toxic chemical that frequently employed in chemical methods is triethyl amine [37], oleic acid [38], thioglycerol [39], and polyvinyl alcohol (PVA) [40] and ethylenediaminetetraacetic acid (EDTA) [41] which is typically used as a capping and stabilizing agent to control the size of NPs and preventing it from agglomeration. Furthermore, 
some of these hazardous chemicals may reside or bound in the final product of NPs. As such, these may interfere with the biological application as well as limit their usage on animals and human [34]. Collectively, the biological method has gained much interest in the synthesis of metal and metal oxide NPs due to the usage of less toxic chemical, eco-friendly nature and are energy efficient.

The biological synthesis methods of $\mathrm{ZnO}$ NPs is performed by using biologically active products from plants and microbes including bacteria, fungi, and yeast. This method is promising owing to its effectiveness, ecofriendly techniques, inexpensive, simple and mass productivity [42]. The biological synthesis using plant extracts is performed using compounds, which are extracted from different parts of the plant such as leaves, roots, stem, fruit and flowers. Some of the plant extracts tend to have complex phytochemical compounds that act as reducing and capping agent in the synthesis process such as phenol, alcohol, terpenes, saponins and protein [43]. Notably, the biological synthesis of metal and metal oxide using plants have been extensively reviewed [34, 44-46]. Hence, this paper emphasizes the biological synthesis of $\mathrm{ZnO}$ NPs using microbes.

Microbes such as bacteria, fungi, and yeast play an important role in the biological synthesis of metal and metal oxide NPs. In the last decade, the use of microbes has gained increased interest in which there have been many studies conducted using various microorganisms' models. Nevertheless, the biological synthesis of $\mathrm{ZnO}$ NPs using microbes still remains unexplored. Table 1 summarizes several of microbes that mediate the synthesis of ZnO NPs including their size, shape and special applications. Biological synthesis using microbes offers an advantage over plants since microbes are easily reproduced. Nonetheless, there are many drawbacks pertaining to the isolation and screening of potential microbes. The main drawback includes cost-effective of the synthesis processes as it is time-consuming and involves the

Table 1 Microbes mediated synthesis of zinc oxide nanoparticles

\begin{tabular}{|c|c|c|c|c|}
\hline Microbes & Size, nm & Shape & Application & Reference \\
\hline \multicolumn{5}{|l|}{ Bacteria } \\
\hline Aeromonas hydrophila & 57.7 & Spherical & Antimicrobial & [16] \\
\hline Bacillus licheniformis MTCC9555 & 250 & Flower & Dye removal & [47] \\
\hline Bacillus megaterium (NCIM2326) & $45 \sim 95$ & Rod and cubic & Antimicrobial & [15] \\
\hline Halomonas elongate IBRC-M 10214 & $18.11 \pm 8.93$ & Multiform & Antimicrobial & [48] \\
\hline Lactobacillus johnsonii & $4 \sim 9$ & Spherical & - & [49] \\
\hline Lactobacillus paracasei LB3 & $1179 \pm 137$ & Spherical & Antimicrobial & [50] \\
\hline Lactobacillus plantarum VITES07 & $7 \sim 19$ & Spherical & - & [51] \\
\hline Lactobacillus sporogens & $5 \sim 15$ & Hexagonal & Controlling pollutant & [52] \\
\hline Lactobacillus sporogens & 145.7 & Hexagonal & Antimicrobial & [53] \\
\hline Pseudomonas aeruginosa & $35 \sim 80$ & Spherical & Antioxidant & [54] \\
\hline Rhodococcus pyridinivorans NT2b & $100 \sim 120$ & Roughly spherical & UV protection, antibacterial & [30] \\
\hline Sphingobacterium thalpophilum & 40 & Triangle & Antimicrobial & [55] \\
\hline Staphylococcus aureus & $10 \sim 50$ & Acicular & Antimicrobial & [56] \\
\hline Streptomyces sp. & $20 \sim 50$ & Spherical & Antimicrobial & [57] \\
\hline \multicolumn{5}{|l|}{ Fungi } \\
\hline Alternaria alternata (Fr.) Keissl (1912) & $45 \sim 150$ & Spherical, triangular, hexagonal & - & [58] \\
\hline Aspergillus aeneus & $100 \sim 140$ & Spherical & - & [59] \\
\hline Aspergillus fumigatus JCF & $60 \sim 80$ & Spherical & Antimicrobial & [60] \\
\hline Aspergillus fumigatus TFR-8 & $1.2 \sim 6.8$ & Oblate spherical and hexagonal & Agriculture & [61] \\
\hline Aspergillus niger & $61 \pm 0.65$ & Spherical & Antimicrobial & [62] \\
\hline Aspergillus terreus & $54.8 \sim 82.6$ & Spherical & Antifungal & [63] \\
\hline Candida albicans & 25 & Quasi-spherical & Synthesis of steroidal pyrazolines & [31] \\
\hline Fusarium spp. & $>100$ & Triangle & - & [64] \\
\hline \multicolumn{5}{|l|}{ Yeast } \\
\hline Pichia kudriavzevii & $10 \sim 61$ & Hexagonal wurtzite & Antimicrobial and antioxidant & [14] \\
\hline Pichia fermentas JA2 & $\mathrm{n} / \mathrm{a}$ & Smooth and elongated & Antimicrobial & [65] \\
\hline
\end{tabular}


use of chemical for growth medium. The presence of various enzymes, protein and other biomolecules from microbes plays a vital role in the reduction process of NPs. These multiple organic components secreted in the suspension or growth medium attributed to the formation of multiple sizes, shape with mono- and polydispersed NPs [66]. Moreover, the protein secreted from microbes could act as a capping agent that confers stability of NPs formation.

In general, not all microbes are able to synthesize NPs because each microbe has a different metabolic process and enzymes activities. Thus, in this regard, the selection of appropriate microbes (regardless of their enzyme activities and biochemical pathway) is crucial to forming NPs. Generally, the cultures are allowed to grow in the culture medium. Besides, the biological synthesis of metal and metal oxide NPs requires metal precursors, which are usually supplied in the form of soluble salts and precipitated in the suspension containing microbial cells or biological compounds extracts from the microbes. The synthesis reaction is usually completed within minutes or hours depending on the culture conditions, which results in the white deposition in the bottom flasks or changes in the colour of suspensions. Thus, this indicates a successful transformation. Furthermore, several parameters are important to determine the rate of production, yield and morphologies of NPs including the temperature, $\mathrm{pH}$, concentration of metal precursor and reaction time. Figure 1 illustrates the process of a biological method utilizing microbes in the synthesis of metal and metal oxide. The NPs produced are characterized physicochemically to determine their properties including size, shape, surface charge, functional group, and the purity [67].

The synthesis of metal and metal oxide NPs depends on the ability of microbes to tolerate heavy metals. Moreover, it is well-known that high metal stress may have an effect on the various microbial activities [68]. Under stress condition, the microbes tend to reduce ions to respective metals. As such, this demonstrates their capability to act as natural nano-factory [69]. Generally, microbes that inhabit ecological niches rich in metal exhibit high metal resistance due to adsorption of metals and their chelation by intra- and extracellular proteins [70]. Therefore, mimicking the natural biomineralization process could be a promising approach for the synthesis of metal and metal oxide NPs. A number of metalreducing microbes have been isolated to synthesise the metal NPs. A previous study isolated the soil fungus, Aspergillus aeneus from mine in India, which demonstrated a high zinc metal tolerance ability and exhibited the potential for the extracellular synthesis of $\mathrm{ZnO}$ NPs [59]. Similarly, another study isolated Cladosporium oxysporum AJP03 from the metal-rich soil in India [71]. The fungi were found to have high gold metal tolerance ability and secreted high enzymes and protein. Hence,

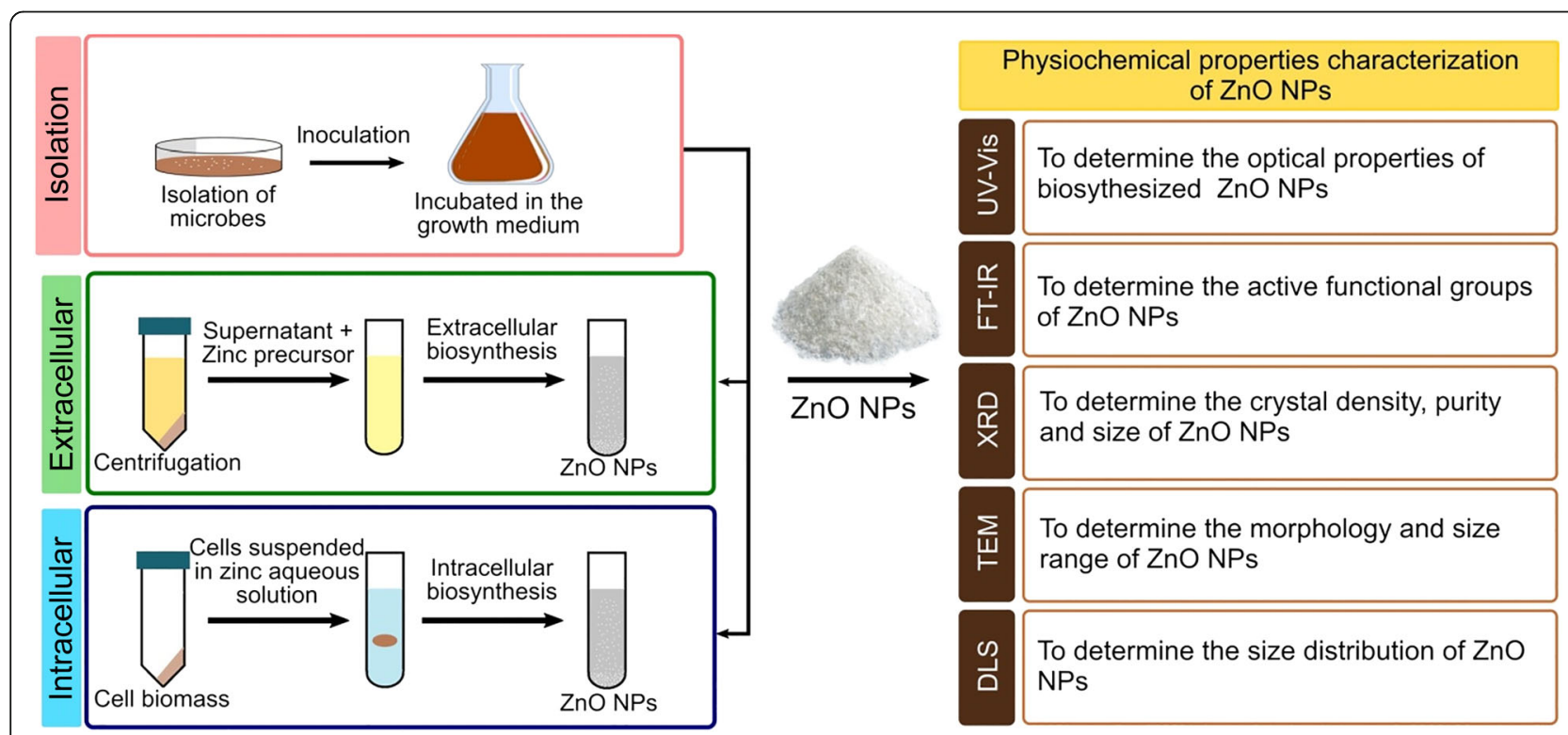

Fig. 1 Microbe-mediated synthesis of metal and metal oxide NPs. Microbial synthesis of ZnO NPs requires the selection of microbes, optimal conditions for cell growth, and route of biosynthesis (intra- or extracellular). The ZnO NPs precipitates are washed repeatedly with distilled water followed by ethanol and afterwards dried at $60^{\circ} \mathrm{C}$ overnight to obtain a white powder of ZnO NPs. Various physicochemical techniques are used to characterize the properties of NPs, including size, shape, surface charge, functional groups, and purity, by using ultraviolet-visible spectroscopy (UV-Vis), Fourier transform infrared spectroscopy (FTIR), X-ray diffraction (XRD), transmission electron microscopy (TEM), and dynamic light scattering (DLS) 
the fungi was identified as a potential candidate for the extracellular synthesis of gold NPs.

Numerous microbes have been exploited to synthesise $\mathrm{ZnO}$ NPs in which bacteria are preferred due to the ease of handling and genetic manipulative attributes compared to other eukaryotic microorganisms [72]. The reproducible bacteria such as lactic acid bacteria (LAB) have attracted increased attention in bacteria mediated synthesis of NPs due to their non-pathogenic properties and high production of various enzymes. Moreover, LAB also recognized as the health beneficial bacteria, which are abundant in the food products [52]. Furthermore, the LAB are facultative anaerobic bacteria that are known to have negative electrokinetic potential. This causes LAB to be easily attracted to the metal ions for the NPs synthesis under both oxidizing and reducing conditions [50, 52]. Apart from that, LAB are Grampositive bacteria that have a thick cell wall layer consisting of peptidoglycan, teichoic acid, lipoteichoic acid, protein, and polysaccharides [73]. This layer acts as a site for biosorption and bioreduction of metal ions. Additionally, LAB are able to produce exopolysaccharides, which serve as a compound to protect the cell against metal ions and may act as an additional site for biosorption of metal ions [74]. Selvarajan and Mohanasrinivasan [51] demonstrated the intracellular synthesis using Lactobacillus plantarum VITES07 that produced a pure crystalline and spherical shape of $\mathrm{ZnO}$ NPs with the size ranged from 7 to $19 \mathrm{~nm}$. The authors reported that NPs produced were moderately stable in which the biomolecules secreted by the LAB acted as a capping agent in the synthesis process. Moreover, studies by Mishra et al. [53] and Prasad and Jha [52] demonstrated that using Lactobacillus sporogens to synthesis $\mathrm{ZnO}$ NPs could produce a similar hexagonal shape with different sizes.

The biological synthesis of $\mathrm{ZnO}$ NPs using fungi is a promising approach due to their high tolerance to higher metal concentration, high binding capacity and their ability in metal bioaccumulation over bacteria [75]. Moreover, the fungi exhibited the ability to secrete a large number of extracellular redox proteins and enzymes. As such, this contributed to the reduction of the metal ions into NPs in larger amounts, which is suitable for the large-scale production [66]. The higher amount of protein secreted in the medium by the fungi acted as capping protein that further bound and encapsulated the NPs surface and conferred to the stability. For instance, Raliya and Tarafdar [61] demonstrated the synthesis of $\mathrm{ZnO}$ NPs by using Aspergillus fumigates TFR- 8 that resulted in the formation of NPs with the average diameter size of $3.8 \mathrm{~nm}$ and high monodispersity particles (uniformly distributed) without any agglomeration. Moreover, the authors suggested that the protein secreted by the fungi was bound and encapsulated the spherical NPs and prevented the NPs from agglomerate. Subsequently, the stability of NPs was examined for 125 days by measuring the size using particle size analyzer. The results demonstrated that NPs were stable until day 90 and the size increased thereafter due to the agglomeration. This concludes that protein could act as a capping agent to stabilize the NPs up to 90 days. In addition, filtrate-cell free supernatant (FCF) of Alternaria alternate was used in the synthesis of $\mathrm{ZnO}$ NPs. On that account, the FCF was found to produce NPs after the precipitation of zinc sulfate solution with the size of $75 \pm 5 \mathrm{~nm}$. In addition, the FTIR absorption spectra analysis demonstrated the presence of protein and other organic compounds on the $\mathrm{ZnO}$ NPs produced. This results corroborated with the previous study that suggested the fungi can generate a high extracellular protein, which bound on the surface of NPs in order to stabilize and prevent it from the aggregation [58]. Therefore, the use of fungi for the synthesis of NPs is favourable as the fungi are efficient in secreting of extracellular enzymes and protein.

Similar to fungi, yeast has been proven to synthesize metallic NPs due to their higher tolerance to the toxic metal. A study conducted by Moghaddam et al., [14] demonstrated that a new isolated Pichia kudriavzevii yeast strain was able to synthesize $\mathrm{ZnO}$ NPs with $\sim 10-61 \mathrm{~nm}$ of the size range of NPs produced. The formation of NPs were reported to depend on the reaction duration, which was found to play an important role in the size, shape and distribution of ZnO NPs. Moreover, Chauhan et al. [65] demonstrated an extracellular synthesis of silver NPs and $\mathrm{ZnO}$ NPs using Pichia fermentans JA2 isolated from the pulp of spoiled fruits. Moreover, the UV-vis spectra results indicated a strong and broad peak at 425 $\mathrm{nm}$ and $374 \mathrm{~nm}$ implying the successful formation of silver and $\mathrm{ZnO}$ NPs, respectively.

The microbes mediated synthesis of $\mathrm{ZnO}$ NPs seems to be eco-friendly and safe as it does not involve the use of any toxic and hazardous chemical in the synthesis process. In addition, the biologically active compounds secreted by the microbes were acted as a reducing and capping agents. Thus, this approach is more advantageous than the conventional methods. Furthermore, fungal mediated synthesis seems to be a promising candidate for the synthesis as it produces more biologically active compounds than the other microbes. Nevertheless, in term of the cells growth activity, the bacteria are promising compared to the other alternatives. Moreover, the mechanisms of biological synthesis of ZnO NPs among the microbes are different and are not fully understood yet, hence, further investigation is needed. 


\section{Mechanisms of microbes mediated synthesis of NPs} Evidence has shown that enzymes, protein and other compounds produced by microbes play a vital role in the synthesis process. Nonetheless, to date, the data on the identification of chemical components responsible for the synthesis of NPs has been scant. Microbes exhibit the intrinsic potential to synthesise NPs of inorganic materials, which may be routed either by the intracellular or extracellular pathway. Extracellular synthesis is more advantageous and has been widely applied compared to the intracellular route. This is mainly due to the fact that it could be used to synthesise large quantities and involves simple downstream processing that eliminates various steps of synthesis, easy separation and industrialization. While the recovery process of NPs in the intracellular synthesis requires additional step such as harvesting the cell biomass by centrifugation and subjected to several cycle ultra-sonication for cells disruption to obtain the purified NPs [76]. Nonetheless, the specific mechanism with regard to this has not been completely elucidated.

\section{Intracellular mechanisms of microbial synthesis}

In the intracellular synthesis pathway, the cell walls of microbes and ions charge play an important role in the synthesis of NPs. This involves distinctive ion transportation in the microbial cell in the presence of enzymes, coenzymes and others. The cell wall of microbes consists of a variety of polysaccharides and protein, which provides active sites for binding of the metal ions [77]. Moreover, not all microbes are able to synthesize metal and metal oxide NPs. Evidence has shown that heavy metal ions exhibit great threat to the microbes in which when there is a threat, the microbes will react by gripping or trapping the ions on the cell wall through the electrostatic interactions [51]. This is due to the fact that metal ion is attracted to the negative charge from the carboxylate groups (specific enzymes, cysteine, polypeptides) that is present on the cell wall [78]. Furthermore, the trapped ions are reduced into the elemental atom initiated by the electron transfer from $\mathrm{NADH}$ by $\mathrm{NADH}$-dependent reductase that acts as an electron carrier, which is embedded in the plasma membrane. Finally, the nuclei grow to form NPs and accumulate in the cytoplasm or in the cell wall (periplasmic space). On the other hand, the protein or peptides and amino acids such as cysteine, tyrosine and tryptophan exist inside the cells are responsible for providing stabilization of NPs $[79,80]$. Figure 2 demonstrates the mechanisms of the microbes mediated intracellular synthesis of ZnO NPs.

Mukherjee et al. [81] demonstrated the intracellular mechanisms using Verticillium sp. for the synthesis of NPs involving three steps, which are trapping, bioreduction and capping. The interaction forces between metal ions and the enzymes present on the cell wall reduce the metal ion within the cell wall leading to the aggregation of metal atoms and formation of metal NPs. The authors also reported the presence of metal NPs on the cytoplasmic membrane by transmission electron microscopy (TEM) analysis, which suggested that the formation of NPs occur in both the cell wall and the cytoplasm of the cell. The small metal ions diffused across the cell wall

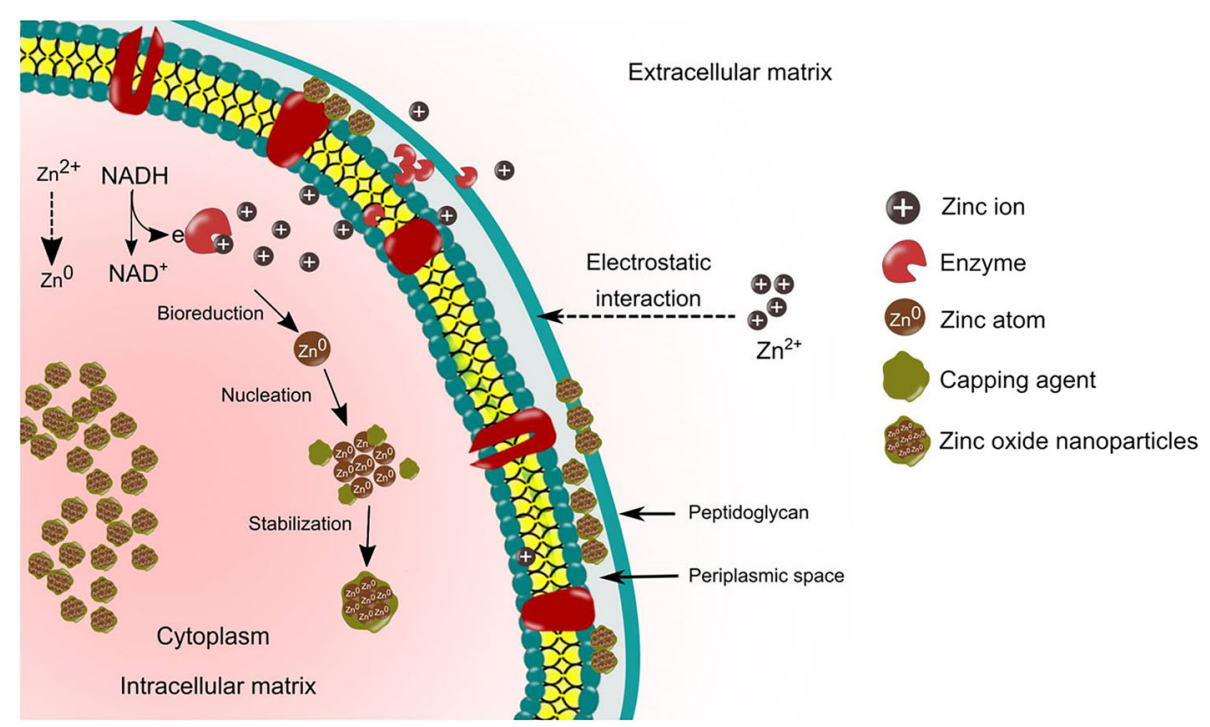

Fig. 2 Schematic representation of intracellular synthesis mechanisms of ZnO NPs. The intracellular mechanisms involve the transportation of metal ions into the cell wall by electrostatic attraction. The metal ions are reduced to a metal atom by the enzymes found in the cell wall and then initiate the nuclei growth to form NPs in periplasmic space and cytoplasm. The intracellular synthesis requires ultrasonication to obtain the purified NPs 
and entered the cytoplasmic membrane. The bioreduction of metal ions into NPs occurred with the presence of local enzymes. Similarly, the intracellular synthesis of gold NPs by utilizing Rhodococcus sp. was reported to occur on the cell wall and cytoplasmic membrane that produced 5 to $15 \mathrm{~nm}$ size of NPs with better monodispersity form [82].

The intracellular, extracellular route or surface production of NPs have been reported to be $\mathrm{pH}$-dependent. A slower rate of intracellular synthesis of silver NPs synthesis by using Meyerozyma guilliermondii KX008616 was observed at $\mathrm{pH} 3$. Moreover, TEM image analysis revealed that small NPs population existed in the cytoplasms in a cluster or nanoaggregates form. Additionally, the NPs were also observed to be located away from the cell wall. The authors suggested that the biomolecules found on the cell such as protein and polysaccharides that are involved in the bioreduction of NPs were inactivated under an extremely acidic condition. Consequently, this caused the metal ion to move into cytoplasms [83]. In another study, the deposition of gold NPs synthesis using Shewanella alga cells was reported to depend on the $\mathrm{pH}$ conditions. At $\mathrm{pH} 7$, the NPs were deposited in the periplasmic space of the cells whereas, at $\mathrm{pH} 2$, the NPs were observed to be deposited in the cytoplasm and larger NPs were deposited extracellularly (outside the cell) [84]. While in other cases, some bacteria species are $\mathrm{pH}$ dependent, the membrane-bound oxidoreductases of $L$. sporogens that were used for the synthesis of $\mathrm{ZnO}$ NPs were activated under a low $\mathrm{pH}$. This suggests that lower $\mathrm{pH}$ ambient is a prerequisite for the synthesis of NPs [52]. Similarly, this was in agreement with a previous study that reported the biological synthesis of $\mathrm{ZnO}$ NPs by membrane-bound oxidoreductases of L. plantarum VITES07, which was $\mathrm{pH}$-sensitive [51].

\section{Extracellular mechanisms of microbial synthesis}

Numerous studies reported that extracellular synthesis is a nitrate reductase-mediated synthesis, which is responsible for the reduction of metal ions into metal NPs [30, $65,85-87]$. The extracellular synthesis pathway involves enzyme-mediated synthesis which located on the cell membrane or the releasing of the enzyme to the growth medium as an extracellular enzyme. Nitrate reductase is an enzyme in the nitrogen cycle that catalyses the conversion of nitrate to nitrite. For instance, the bioreduction of $\mathrm{Zn}^{2+}$ was initiated by the electron transfer from $\mathrm{NADH}$ by $\mathrm{NADH}$-dependent reductase that acts as an electron carrier [88]. Consequently, the $\mathrm{Zn}^{2+}$ obtained electron and reduced to $\mathrm{Zn}^{0}$. Subsequently, this resulted in the formation of $\mathrm{ZnO}$ NPs. The schematic of the extracellular synthesis mechanisms is illustrated in Fig. 3.

Kundu et al. [30] conducted an experiment to determine the involvement of the secreted protein or enzyme by the multi-metal tolerant bacteria, Rhodococcus pyridinivorans NT2 for the synthesis of ZnO NPs. The

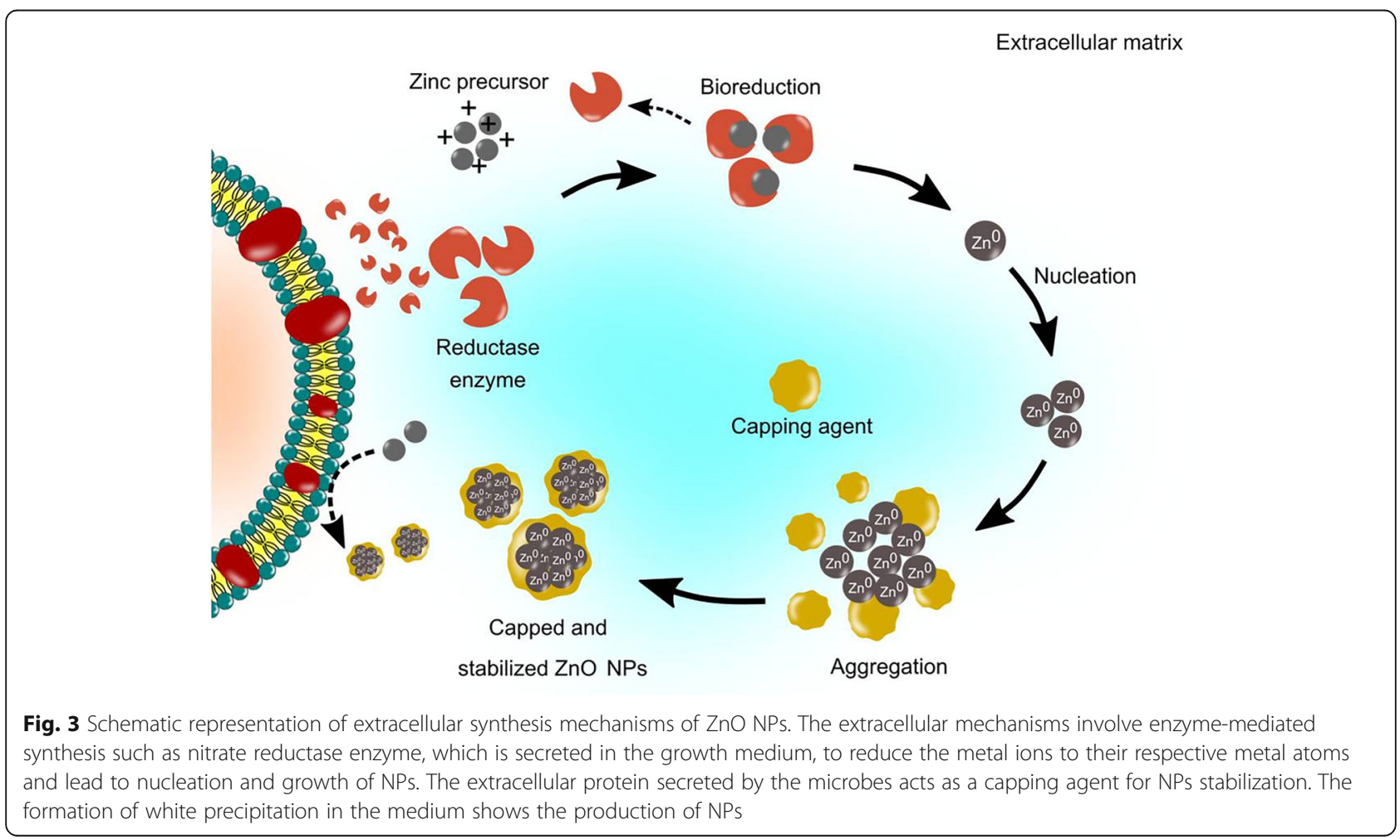


bacteria biomass were exposed to zinc ion and millipore water as a control. The extracellular protein from the supernatant was determined by a protein expression profile. The results of Lowry's assay demonstrated that the concentration of extracellular protein secreted by the bacteria biomass that was exposed to zinc ions was twice higher than in the control, which was $1113 \pm$ $6.3 \mu \mathrm{g} / \mathrm{mL}$ and $554 \pm 7.1 \mu \mathrm{g} / \mathrm{mL}$ for control. Moreover, the electrophoretic profile by one-dimensional SDSPAGE revealed that the presence of a molecular mass of $43 \mathrm{kDa}$, which was an NADH-dependent reductase. The findings indicated that NADH-dependent reductase resulted in the formation of $\mathrm{ZnO}$ NPs.

Studies have shown that protein produced and secreted by microbes play an important role in the NPs synthesis [57, 89-91]. Nevertheless, some studies suggested that the native form of the protein is not compulsory for the NPs synthesis process. A study by Jain et al., [59] revealed that amino acids present in the protein were found to interact with the $\mathrm{Zn}^{2+}$ ions to form NPs. The study also investigated the ability of denatured (heat treated) and native (untreated) protein present in the fungal cell-free filtrate suspension for the synthesis of $\mathrm{ZnO}$ NPs. The results demonstrated that both heats treated and untreated samples were able to synthesize ZnO NPs. Notably, the absorbance spectra result by UVVis demonstrated a higher reaction rate on the heat treated protein compared to the untreated. This indicates that the synthesis of $\mathrm{ZnO}$ NPs was higher in the heat-treated samples. Hence, the results confirmed that the presence of the native form of the protein is not mandatory for the synthesis process. This may attribute to the fact that, the interaction between hydrogen bond and non-polar hydrophobic was disrupted during the heating process. Consequently, this resulted in the exposed contact of amino acids with zinc ions that led to the formation of $\mathrm{ZnO}$ NPs [59]. Moreover, the authors also suggested that the biosynthesis of metal NPs was non-enzymatic due to the denaturation of the structure of the enzyme during heat treatment.

In some cases, the non-enzymatic mediated synthesis depends on the certain organic functional groups present on the microbial cell wall, which facilitates the reduction of metal ions. The live cell biomass and dead cell (heat killed by autoclaving) of Corynebacterium glutamicum were used to synthesize silver NPs. After sonication of the cell, the UV-Vis spectra results demonstrated a strong plasmon resonance between 400 and $450 \mathrm{~nm}$ for both samples. Both samples were further incubated for a few days. The results indicated that the peak area and height of the UV-Vis spectrum for the dead cell were comparatively higher compared to live cell samples. This indicates a higher productivity of silver NPs [92]. The authors also validated the results by investigating the total organic content (TOC) for both samples and revealed that the TOC in dead cells was twice higher than the live cell. This indicates the release of organic molecules (reducing agent) from the cell due to rupturing of the cell walls during the heat-killed in which the silver ions obtained the access to more organic molecules and hence a higher amount of reduction occurred [92]. Therefore, the study confirmed that the formation of NPs could occur without the involvement of biological enzymes or metabolites compounds. Nevertheless, this was in contrast to Korbekandi et al. [74], which suggested that the NPs synthesis was an enzymatic reaction. The study demonstrated that the boiling of the Lactobacillus casei biomass killed the bacterial cells and denatured the enzymes. The results demonstrated the presence of NPs in the reaction mixture with active biomass, whereas, no absorbance was observed in the reaction mixture with boiled biomass. This indicates that the enzymes found in the medium were denatured while the dead cells were unable to secrete enzymes resulting in absence of synthesis of NPs. Thus, it can be speculated that the inconsistent finding was due to variations in the methods and species of microbes used for the synthesis of NPs.

The protein secreted by microbes could also act as a capping agent despite acting as a reducing agent. As such, this facilitated the higher stabilization and dispersion of NPs [30]. As such, several studies demonstrated the involvement of protein as a capping agent. For instance, Velmurugan et al., [64] investigated the role of protein in live, dried and dead biomass of Fusarium spp. as a capping agent in the synthesis of ZnO NPs. The SEM-EDS results on the NPs produced by live and dried biomass demonstrated signals of $\mathrm{Na}$ and $\mathrm{K}$. This indicated the bound of proteins on the surface of zinc crystallites. This result was supported by the FTIR results, which demonstrated clear peaks. The findings revealed the presence of protein and amide, I and II bands at $1100,1400,1650,2900$ and $3000 \mathrm{~cm}^{-1}$, respectively. Nevertheless, there was no protein signal detected in zinc crystal produced by the dead biomass. Similarly, Bao et al. [93] evaluated the chemical composition of the ligands capping on the NPs. The FTIR results demonstrated two absorption bands at 1650 and $1566 \mathrm{~cm}^{-1}$, which indicated the typical amide I and II absorptions of protein molecules, respectively. Further verification was carried out via protein purification by using highperformance liquid chromatography (HPLC) to analyze the molecular mass of the capped protein. The results demonstrated the presence of two proteins with molecular mass of $7.7 \mathrm{kDa}$ and $692 \mathrm{kDa}$. Additionally, the authors suggested that the yeast used in the experiment facilitated the synthesis of NPs and generated protein ligands to act as a capping agent, which inhibited the aggregation of NPs. 
Effect of various parameters on the optimization process of NPs synthesis

Microbes-mediated synthesis of NPs has the potential to be a great alternative to chemical and physical methods, despite the main drawback in applying biological synthesis of NPs, which refers to the difficulty in controlling both the size and the shape of NPs. The main major concerns in using microbes are to increase yield production for industrial scale, which demand further investigation. It has been widely reckoned that the physicochemical properties of NPs are highly dependent on their size and morphology structures. Studies have proven the direct effects of NPs size and shape on their performance. Sadeghi et al., [94] revealed that the nanoplate-shaped NPs exhibited good antibacterial activity due to their large surface area, in comparison to those with nano-rod shape. In another study, ZnO NPs at $12 \mathrm{~nm}$ effectively inhibited the growth of pathogenic bacteria, when compared to those at $212 \mathrm{~nm}$ [95]. Therefore, in order to generate effective size distribution, morphologies, and yield production of NPs, it is necessary to optimize both the cultural condition and the varied physical parameters, including $\mathrm{pH}$, temperature, metal ions concentration, microbial age, and reaction time. The biological synthesis of NPs seems to gain better commercial acceptance if the NPs are produced in high yield with the desired size and shape. The schematic representation of parameters for producing the desired NPs is portrayed in Fig. 4.

\section{Effect of $\mathrm{pH}$}

Generally, $\mathrm{pH}$ is a key factor that has a major role in the synthesis of metal NPs, mainly because $\mathrm{pH}$ has the ability to alter the shape of biomolecules that is responsible in capping and stabilizing the NPs [96]. Gericke and Pinches [97] assessed the biosynthesis of gold NPs using Verticillium luteoalbum by varying the $\mathrm{pH}$ level to determine its impact on the size and shape of the generated NPs. The outcomes displayed a majority smaller size of NPs with spherical shape obtained at $\mathrm{pH} 3$, in comparison to those retrieved for $\mathrm{pH}$ values 7 and 9 that predominantly produced larger NPs with irregular and undefined shapes. Optimization of $\mathrm{pH}$ may also be influenced by the species of microbes applied in the synthesis. For instance, an acidophilic bacterium, Lactobacillus casei, resulted in increased absorbance of silver NPs production as the $\mathrm{pH}$ value was reduced; indicating that growth and enzymes activity of $L$. casei are better in weak acidic environment [74]. In the case of alkaline condition, Gurunathan et al., [98] asserted that hydroxide ion is essential to decrease metal ions. The authors observed rapid increment in silver conversion within less than 30 min' reaction time at $\mathrm{pH}$ 10 ; signifying that the protein, which served as a reducing agent, was present in the supernatant and was active in reducing power under alkaline conditions. Additionally, the authors confirmed their results by observing the NPs with TEM analysis that recorded smaller size of NPs ranging between 10 and $15 \mathrm{~nm}$. The finding is in agreement with that reported by Ma et al., [99], which recorded increase in absorbance peak of silver NPs with increment of $\mathrm{pH}$ value. The synthesis of silver NPs using Fusarium oxysporum at $\mathrm{pH} 6$ resulted in the smallest size, whereas higher $\mathrm{pH}$ generated the biggest size, which indicated the catalytic activity of enzymes involved in the synthesis of NPs that appeared to be deactivated under alkaline condition, thus causing an increase in the size of NPs [29].

\section{Effect of temperatures}

Numerous researches have investigated the impacts of various temperatures on the size and yield production of NPs. Mohammed Fayaz et al., [100] assessed the effects of temperatures on NPs size produced by Trichoderma viride at $10^{\circ} \mathrm{C}, 27^{\circ} \mathrm{C}$, and $40{ }^{\circ} \mathrm{C}$. The UV-Vis spectra outcomes showed that lower wavelength regions at 405 nm were obtained at $40^{\circ} \mathrm{C}$ and higher wavelength regions at $420 \mathrm{~nm}$ and $451 \mathrm{~nm}$ were obtained at $27^{\circ} \mathrm{C}$ and $10{ }^{\circ} \mathrm{C}$, respectively, indicating increment in NPs size at higher wavelength regions. The author also verified their results with TEM analysis that showed a high temperature

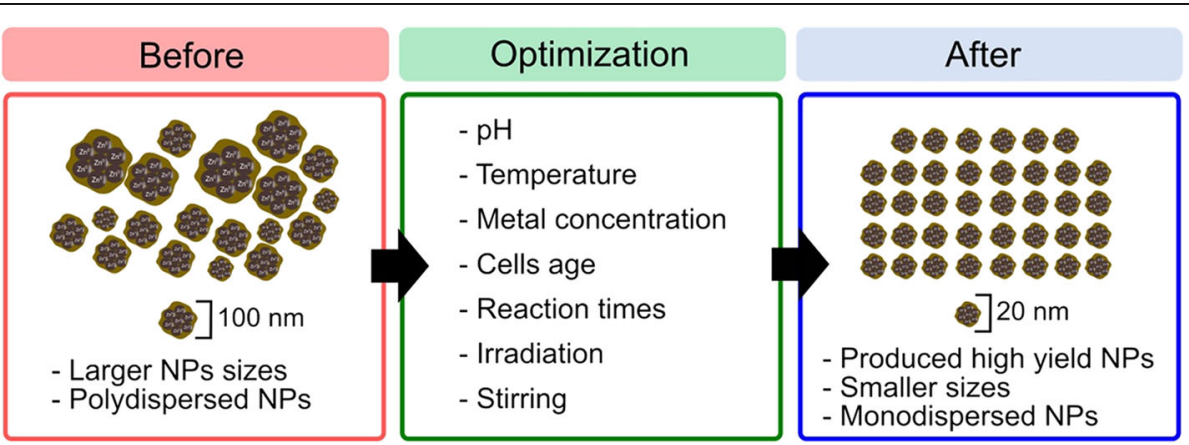

Fig. 4 Strategies for optimizing the synthesis of ZnO NPs. The synthesis of NPs is associated with different physicochemical parameters including $\mathrm{pH}$, temperature, precursor concentration, microbe age, reaction times, irradiation, and stirring. Each of these parameters contributes to variations in size, shape, monodispersity, and yield of NPs 
of $40^{\circ} \mathrm{C}$ generated smaller monodisperse NPs size ranging between 2 and $4 \mathrm{~nm}$, while at a lower temperature, larger NPs were produced. In another study, maximum production of silver NPs synthesized by Sclerotinia sclerotiorum was obtained at $80^{\circ} \mathrm{C}$ with $10-15 \mathrm{~nm}$ size range. This postulated that higher temperature increased the kinetic energy, thus leading to rapid synthesis rate and maximum NPs with a smaller size [101]. The decrease in particle size with increased temperature is normally due to increment in reaction rate at higher temperature. This causes the metal ion to be consumed rapidly in forming nuclei, while the size is reduced initially due to reduction in the aggregation of the growing NPs [98].

\section{Effect of precursor concentration}

The impact of various precursor salt concentrations on the synthesis of metal NPs using soil fungus Cladosporium oxysporum revealed that the optimum concentration of precursor salt at $1.0 \times 10^{-3} \mathrm{~mol} / \mathrm{L}$ gave maximum NPs yield. Nonetheless, at concentrations $2.0 \times 10^{-3}$ and $5.0 \times 10^{-3} \mathrm{~mol} / \mathrm{L}$, no NPs was generated due to the insufficient biomolecules in minimizing the high amount of metal ions present [71]. This finding is in agreement with that reported by Jamdagni et al. [12], who discovered that absorbance of $\mathrm{ZnO}$ NPs by UV-Vis spectra increased with increment of precursor concentration $\left(2.5 \times 10^{-5}\right.$ to $\left.1.0 \times 10^{-4} \mathrm{~mol} / \mathrm{L}\right)$. They added that further increment in concentration $\left(2.0 \times 10^{-4} \mathrm{~mol} / \mathrm{L}\right)$ resulted in broad peak, while decrease in absorbance signified reduction in the synthesis of ZnO NPs. The influence of metal ion concentration on the synthesis of silver NPs using Penicillium aculeatum Sul suggested that high concentration of metal ions increased the aggregation of NPs, which resulted in the formation of larger NPs size. The authors reported that maximum production of NPs yield was obtained at absorbance peak of $415 \mathrm{~nm}$ by UVvis spectra, whereby as the concentration increased to $2.5 \times 10^{-3} \mathrm{~mol} / \mathrm{L}$, the absorbance peak shifted to $435 \mathrm{~nm}$; signifying the increased size of NPs formation [99]. Meanwhile, another study reported that increment in metal ions concentration to a certain point generated NPs with smaller size. The study of silver NPs synthesis by using extracellular supernatant of Escherichia coli revealed that increment in silver ion concentration up to $5 \times 10^{-3} \mathrm{~mol} / \mathrm{L}$ minimized the size of NPs by about 15 $\mathrm{nm}$, in which the authors speculated that the silver ions bound on the growing particles to form a coat that prevented them from aggregation [98].

\section{Effects of microbial age and reaction time}

The growth phase of cell is essential for the synthesis of NPs. Since microbes generate various enzymes at different growth phases, controlling the cell age may be useful in producing high yield of NPs. Gericke and Pinches
[97] reported that the biomass of Verticillium luteoalbum harvested at $24 \mathrm{~h}$ produced a high yield of gold NPs, when compared to biomass harvested at $72 \mathrm{~h}$. This may be attributed to the fact that cell at the early exponential stage actively generated high concentrations of enzymes and protein, which resulted in high reduction of metal NPs. In a study pertaining to ZnO NPs synthesis that employed Pichia kudriavzevii, prolonged reaction time was discovered upon exposure to metal ions at $36 \mathrm{~h}$ that produced aggregate with irregular-shaped NPs, whereas reaction time of 12 and $24 \mathrm{~h}$ generated the smallest size of NPs [14]. On the other hand, ZnO NPs synthesis that employed Lactobacillus sp. yielded NPs with an average size of $7 \mathrm{~nm}$ for 5 to 10 min of reaction time [51].

In summary, microbes have been reckoned to generate NPs. Nevertheless, optimization process is essentially required to produce the desired NPs size, shape, yield, and homogeneous particles (monodispersity), mainly because these NPs have a significant role in determining their unique properties for specific applications. The study is still ongoing because each microbe has a wide range of abilities in producing NPs and further investigation is required to improve the synthesis process for implementation in practice.

\section{The potential application of $\mathrm{ZnO} N \mathrm{Ns}$ in animal industry} $\mathrm{ZnO}$ NPs is one of the largest produced metals oxide [2] which has been extensively studied due to its unique properties of semiconductor characterized by broad direct band gap width $(3.37 \mathrm{eV})$ with high excitation binding energy $(60 \mathrm{meV})$ and deep borderline ultraviolet (UV) absorption [102]. In this regard, its unique and attractive properties have made it a promising tool for application in many industrial areas including pharmaceutical [103], cosmetic [104], photocatalyst [102], UV light emitting devices [105] and agriculture industries [9, 106]. Zinc plays a significantly important role in a variety of physiological processes in human, animals as well as plants. It is extensively present in all body tissues including muscles, bones, and skin [107], In addition, zinc is an integral component in numerous enzyme structures [11] and has a crucial part in hormone secretion, growth, reproduction, body immune system, antioxidant defence system and many other biochemical processes in the body [17]. Figure 5 illustrates the role of zinc in poultry and livestock.

$\mathrm{ZnO}$ NPs possess many valuable features including their eco-friendly materials, biocompatibility, biodegradability and most importantly their bio-safety traits which have been graded by the US Food and Drug Administration [4]. Furthermore, $\mathrm{ZnO}$ NPs have been found to exhibit non-toxic properties in human cells at a certain concentration level [108]. In fact, biological mediated 


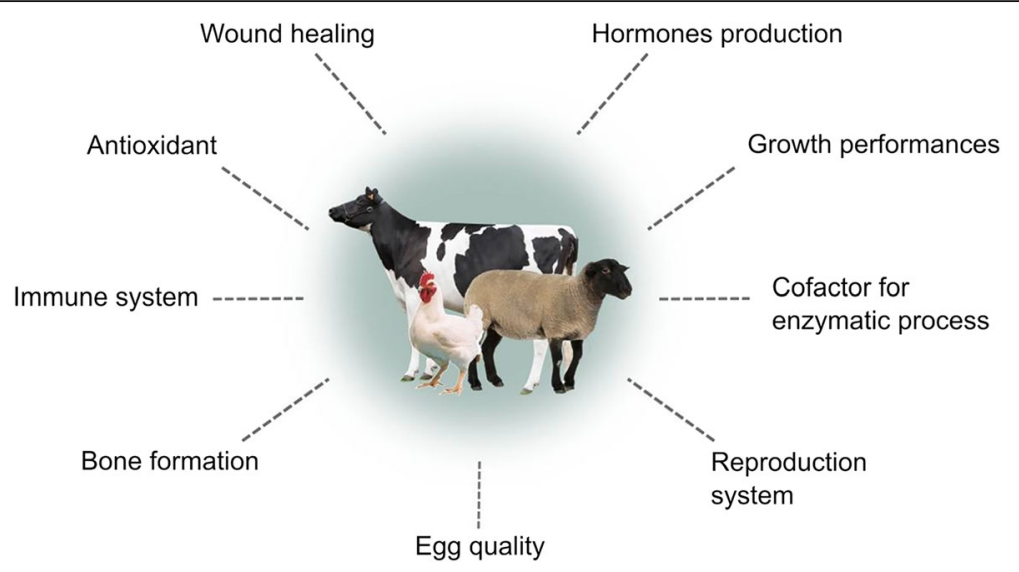

Fig. 5 Role of zinc supplementation in poultry and livestock. Zinc is an important trace element for physiological and biological functions of the body. The utilization rate of zinc in the animal's body is low and therefore the addition of ZnO NPs to animal feeds is believed to increase zinc uptake and bioavailability in the body

synthesis of ZnO NPs does not involve any hazardous chemical and material, thus making their application in living organisms safe. The efficiency of $\mathrm{ZnO}$ NPs is greater than their counterparts due to their high surface to volume ratios. Therefore, the use of bulk zinc oxide has been widely replaced with ZnO NPs in many aforementioned applications. With the onset of biological mediated synthesis of NPs, the application of ZnO NPs has extended into the next level of application particularly in the field of biomedical and nutrition in human and animals. In the recent year, ZnO NPs have been extensively investigated for use in animal husbandry and production as an antimicrobial agent for disease prevention and as a feed supplement in animals diet to improve the utilization efficiency of trace elements in the animal's body.

\section{Potential role as an antimicrobial agent in animal industry}

The continuous usage of conventional antibiotic has led to the growth and spread of multidrug-resistant strains [109]. Thus, the discovery and development of new approaches as an alternative to a conventional antibiotic is necessary. ZnO NPs produced by the biological enzymatic process have varied application and have been prominently studied recently on their excellent antimicrobial activities such as antibacterial [13] and antifungal [12]. The distinctive features of NPs such as their small size in relation to a large surface area, composition and morphology allow the NPs to interact with the bacterial cell surface and penetrate the cell's core and subsequently exhibit bactericidal mechanisms [110]. Moreover, the inorganic antibacterial properties of NPs' materials have the ability to withstand extremely harsh conditions and high temperatures compared to organic materials [111]. Microbes mediated synthesis of $\mathrm{ZnO}$
NPs could become potential antimicrobial agents as some of the bacterial species are able to produce a variety of compounds that exhibit antimicrobial properties which are known as bacteriocin. Bacteriocin is a small heat-stable peptide which has a bactericidal effect on pathogenic microorganisms [112]. The bacteriocin derived from the microbes could act as a reducing agent for the synthesis of metal NPs [113]. In addition, previous study has proved that this small peptide could also bind to the surface of NPs as a capping agent which in turn enhance the antimicrobial effects of metal NPs [112-116]. Nonetheless, there is a lack of study on employing the biological synthesized of ZnO NPs by microbes on animal production which possibly due to their limitation on mass production for large scale application. Furthermore, many in vitro studies have been conducted on the antibacterial ability of ZnO NPs [14-16, 67], however, the exact mechanism of antibacterial activity of $\mathrm{ZnO}$ NPs remains elusive.

\section{Antibacterial mechanisms of ZnO NPs}

Scientists have suggested a few possible bactericidal mechanisms, some proposed that smaller NPs have greater surface reactivity and easier cell penetration that released the $\mathrm{Zn}^{2+}$. The release of $\mathrm{Zn}^{2+}$ from $\mathrm{ZnO}$ NPs is one of the main propositions in antibacterial mechanisms which are known to inhibit several bacterial cells activities including active transport, bacteria metabolism and enzymes activity. Subsequently, the toxicity properties of $\mathrm{Zn}^{2+}$ on the bacterial cell biomolecules induced the cell to death [117]. Moreover, the release of $\mathrm{Zn}^{2+}$ is size and morphology dependent. For instance, the release of $\mathrm{Zn}^{2+}$ in smaller size spherical structures of NPs is higher than in rod structures due to its smaller surface causing equilibrium solubility [118]. While the other proposed antibacterial activity is caused by the formation 
of reactive oxygen species (ROS) which leads to oxidative stress and subsequent cell damage or death. The formation of ROS is a common antibacterial activity adopted by ZnO NPs [34] which are generated under UV exposure and consist mainly of reactive species such as superoxide anion $\left(\mathrm{O}_{2}^{-}\right)$, hydroxyl ion $\left(\mathrm{OH}^{-}\right)$and hydrogen peroxide $\left(\mathrm{H}_{2} \mathrm{O}_{2}\right)$. These reactive species are generated from the surface of the NPs that react with the hydroxyl groups and absorb water $\left(\mathrm{H}_{2} \mathrm{O}\right)$ to create hydroxyl radicals $\left(\mathrm{OH}^{-}\right)$and $\mathrm{H}^{+}$and consequently creates a superoxide anion $\left(\mathrm{O}_{2}{ }^{-}\right)$with the presence of $\mathrm{O}_{2}$ [67]. The $\mathrm{O}_{2}^{-}$will then react with $\mathrm{H}^{+}$to produce $\mathrm{HO}_{2}$ and generate into $\mathrm{H}_{2} \mathrm{O}_{2}$ in the presence of electrons and $\mathrm{H}^{+}$[13]. Eventually, the $\mathrm{H}_{2} \mathrm{O}_{2}$ penetrates the bacterial membrane and damage the cellular components such as lipid, protein and DNA resulting in injuries and cells death [119]. However, $\mathrm{OH}^{-}$and $\mathrm{O}_{2}{ }^{-}$are unable to enter the membrane of bacteria cell due to their negative charge and may be found on the outer surface except for $\mathrm{H}_{2} \mathrm{O}_{2}$ [111].

Another possible mechanism for the antimicrobial activity of $\mathrm{ZnO}$ NPs is through the attachment of NPs to the bacteria cell membrane via electrostatic forces. The positive zeta potential of $\mathrm{ZnO}$ NPs promotes the attachment to the negatively charged bacterial cell which leads to the penetration of $\mathrm{ZnO}$ NPs into the cells [110]. This interaction may distort the membrane plasma structure and damage the bacterial cell integrity, resulting in the leakage of intracellular contents and ends with cell death [16]. In addition, the accumulation of $\mathrm{ZnO}$ NPs in the cell also interfered with the metabolic functions of the bacteria that leads to death. The mechanism of $\mathrm{ZnO}$ NPs antibacterial activity is illustrated in Fig. 6. Therefore, the aforesaid bactericidal mechanisms provide better action modes compared to the conventional therapeutic agents tendency to develop multidrugresistant microorganism.

\section{Antimicrobial activity of ZnO NPs in animal industry}

In the poultry and livestock industry, Salmonella and Campylobacter are common enteric foodborne pathogens which can be found in the gut and skin of the animals $[120,121]$. These pathogenic bacteria can be transmitted from animals to human through the handling of animals and the consumption of contaminated undercooked meat and egg products [122]. Staphylococcus aureus a pathogenic bacteria present in meat product cause food poisoning and is also responsible for bovine mastitis and bumblefoot disease in poultry [123, 124]. Furthermore, S. aureus has the ability to build a resistance rapidly with the prolonged use of antibiotics [125]. Escherichia coli is another pathogenic bacteria

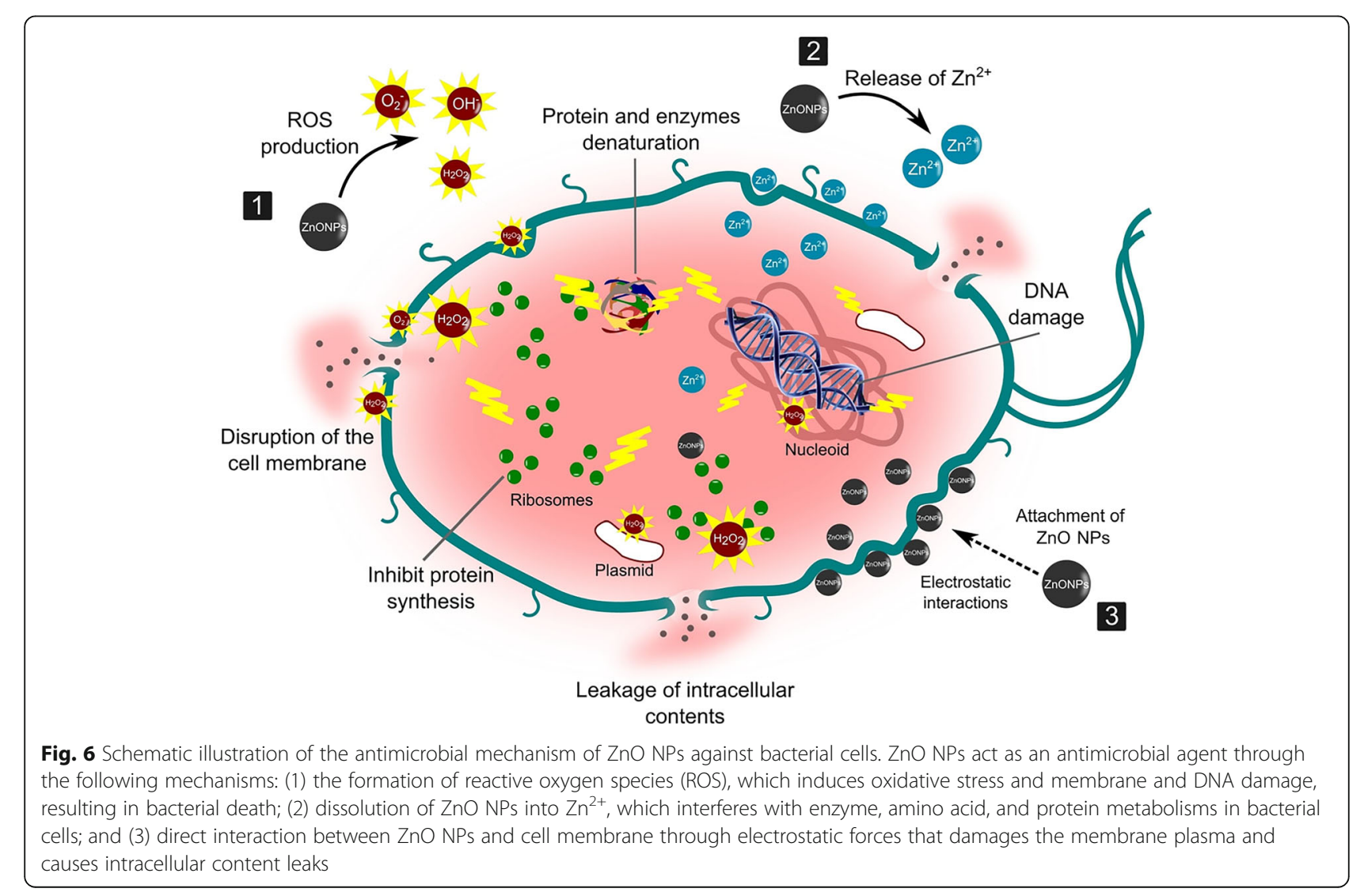


commonly colonized in human and domestic animal gut microbiota. In poultry, E. coli is the major factor of mortality in newly hatched young chicks [126] which contribute to economic losses in the poultry industry. Therefore, NPs has arisen to be a new approach in the reduction of these pathogenic bacteria colonization in animals without the risk of developing multi-drug resistance.

The well-diffusion test using a biologically synthesized of $\mathrm{ZnO}$ NPs against various Gram-positive and Gramnegative bacteria and fungus was carried out to evaluate their antimicrobial activity. The results showed a maximum zone of inhibition was observed in Pseudomonas aeruginosa and Aspergillus flavus, $22 \pm 1.8 \mathrm{~mm}$ and $19 \pm$ $1.0 \mathrm{~mm}$ respectively [16]. Similarly, the extracellular synthesis of $\mathrm{ZnO}$ NPs employing the endophytic bacteria Sphingobacterium thalpophilum showed antimicrobial effects against $P$. aeruginosa [55]. In other studies, the synergistic effects experiment were carried out by combining the $\mathrm{ZnO}$ NPs with various antibiotics including tigecycline, vancomycin, erythromycin and ofloxacin to test their ability in various multidrug-resistant bacteria. The results showed an increase in antibacterial activities in the presence of $\mathrm{ZnO}$ NPs among the resistant bacteria and effective zone of inhibition was observed in Enterococcus sp., Staphylococcus aureus and Proteus mirabilis [65]. While marine yeast mediated synthesis of $\mathrm{ZnO} N P s$ was found to have an effective antibacterial activity against the human pathogens of E. coli and B. subtilis. The well-diffusion test showed a larger inhibition zone against E.coli and B. subtilis at a concentration of $100 \mu \mathrm{g} / \mathrm{mL}$. However, the antibacterial activity of $\mathrm{ZnO}$ NPs was more efficient against $E$. coli compared to $B$. subtilis due to their different cell wall composition for Gram-negative and Gram-positive [57].

Furthermore, the bactericidal activity of $\mathrm{ZnO}$ NPs is dependent upon their size, shape, stability and concentration. A green mediated synthesis of rectangular shaped ZnO NPs employing stevia leaves demonstrate an effective bactericidal activity against $S$. aureus and $E$. coli. The results showed the minimum inhibitory concentration (MIC) value was $2.0 \mu \mathrm{g} / \mathrm{mL}$ and that the rectangular shaped $\mathrm{ZnO}$ NPs had a higher antimicrobial effect at lower concentration [127]. In one comparative study on the antibacterial effect of $\mathrm{ZnO}$ NPs against their bulk particle counterparts, ZnO NPs was found to exhibit higher toxicity effects on B. subtilis, E. coli and $P$. fluorescens, while their counterparts had none or lower toxicity. This indicates particles size do make a difference in toxicity [128]. The results showed NPs size exhibit greater antibacterial activities over their counterparts' size.

A nano-rod shaped $\mathrm{ZnO}$ NPs produced by Bacillus megaterium cell-free supernatant was tested for its antibacterial activity against multidrug-resistant Helicobacter pylori strain. The TEM analysis revealed cells exposed to $\mathrm{ZnO}$ NPs at a concentration of $17 \mu \mathrm{g} / \mathrm{mL}$ for $60 \mathrm{~min}$ showed a disruption of cell membrane causing leakage of the cellular content which induced the cell to death. Whereas the cell unexposed to $\mathrm{ZnO}$ NPs remained complete with intact cell membrane. The authors also suggested that the nano-rods shaped NPs acted like a needle penetrating the bacterial wall and damaging the cells [15].

Mycotoxin is a common contaminant in animal feed produced by fungi-producing mycotoxins such as Aspergillus, Penicillium and Fusarium genera [129]. A high percentage of mycotoxins contamination in animal feed has been reported [130] with adverse effects seen in the animals' performance and health. ZnO NPs were tested for their antifungal potential. The ZnO NPs synthesis by Aeromonas hydrophila showed a maximum inhibition zone of antifungal activity against $A$. flavus $(19 \mathrm{~mm} \pm 1.0$ $\mathrm{mm}$ ) [16]. Moreover, Jamdagni et al., [12] conducted an antifungal test of biological mediated synthesis of $\mathrm{ZnO}$ NPs against Alternaria alternata, Aspergillus niger, Botrytis cinerea, Fusarium oxysporum and Penicillium expansum found $\mathrm{ZnO}$ NPs were effective against all the tested fungi and $A$. niger was found to be sensitive to $\mathrm{ZnO}$ NPs with the lowest MIC value of $16 \mu \mathrm{g} / \mathrm{mL}$. Thus, from this point of view, $\mathrm{ZnO}$ NPs could become a potential antifungal agent substitute for conventional fungicides and possibly prevent the development of fungicides resistance.

Furthermore, one of the most common enteric diseases in poultry and livestock farming is coccidiosis. Coccidiosis is a protozoan disease caused by enteric protozoa of the genus Eimeria infecting the intestinal mucosa and resulting in bloody diarrhea, reduced weight gain and high mortality in poultry and livestock farming [131]. ZnO NPs have also been reported to exhibit anticoccidial properties. Dkhil et al., [132] in an in vivo study on the properties of ZnO NPs anticoccidial activity in mice infected with Eimeria papillata showed that mice infected with $E$. papillata produced $29.7 \times 10^{3} \pm 1500$ oocysts/g of feces compared to the treated infected mice decreased excretion of $12.5 \times 10^{3} \pm 1000$ oocysts/g of feces.

Despite the excellent antimicrobial ability of ZnO NPs against pathogenic microorganisms, their usage as an antimicrobial agent in animal husbandry remains underutilized due to the lack of proposed strategies for in vivo assessment. However, several studies have demonstrated the effects of $\mathrm{ZnO}$ NPs supplementation on the gut microbiota of domestic animals [133, 134]. In an intestinal microbiome study by Yausheva et al. [134], the supplementation of $\mathrm{ZnO}$ NPs in broiler chicken resulted in the highest biological activity on cecal microbiota and the authors recommended $\mathrm{ZnO}$ NPs to be considered as 
a potential bactericidal drug for broiler chicken. In another study, hens fed with ZnO NPs for 9 weeks showed a decrease of bacterial richness in the ileum, particularly Lactobacillus; however, the effect observed was dosedependent [133]. The reduction of Lactobacillus in the gastrointestinal tract is of particular interest because it is a predominant genus in the animal gut [135] that plays a significant role in regulating the level of some pathogenic bacteria [136]. Nonetheless, Yausheva et al. [134] found that even though the supplementation of $\mathrm{ZnO}$ NPs resulted in the decrease in the number of Lactobacillus, there was no increase in the level of pathogenic microorganisms in the cecum of the broiler chicken. This indicates that the supplementation of $\mathrm{ZnO}$ NPs is also able to regulate pathogenic microorganism in the animal's intestinal tract. This is contradictory to the study by Xia et al. [137], which reported an increase in microbiota richness and diversity in the ileum and colon of piglets fed with $600 \mathrm{mg} / \mathrm{kg}$ of $\mathrm{ZnO}$ NPs. Furthermore, the authors also noted the increase in the abundance of Firmicutes, Lactobacillaceae, and Lactobacillus in the colon, which may be beneficial and contribute to a more stable gut microecosystem. Similarly, Milani et al. [138] observed stabilization of gut microbiota on weaned piglets fed with $\mathrm{ZnO}$ NPs at concentrations of 15, 30, and $60 \mathrm{mg} / \mathrm{kg}$. To summarize, the intrinsic properties of $\mathrm{ZnO}$ NPs make them an ideal antimicrobial agent substitute for conventional antibiotics. Moreover, the specific mechanism of $\mathrm{ZnO}$ NPs is different from conventional antibiotics, hence preventing the development of multidrug-resistant bacteria. In addition, numerous in vitro studies on their antimicrobial activity have proven that $\mathrm{ZnO}$ NPs exhibit remarkable capability in inhibiting the growth of a wide spectrum of bacterial species at possibly lower doses. Nonetheless, the main concern in applying $\mathrm{ZnO} \mathrm{NPs}$ as the potential antimicrobial agent in animal husbandry is their destructive effects on the beneficial microorganisms of the intestinal microbiota. Hence, more investigation is needed to elucidate their effects on the gut ecosystem of animals.

\section{ZnO NPs as a dietary supplement in animal industry}

Zinc is an essential micronutrient component for animals. It influences their body's physiological and biological functions including growth, reproduction, wound healing, body immune system, DNA, protein synthesis, oxygen free radical scavenging and as a component of numerous enzymes in animals [9]. The zinc bioavailability in the animal's body is low [139], thus regular dietary intake is required. Generally, the forms of zinc sources used in animal feed are inorganic zinc such as zinc oxide $(\mathrm{ZnO})$ and zinc sulfate $\left(\mathrm{ZnSO}_{4}\right)$ and organic zinc such as zinc propionate, zinc methionine, and zinc acetate [140, 141]. The organic zinc is higher in bioavailability compared to inorganic zinc, but the application of organic zinc in animal diets is limited due to its high cost $[140,142]$. Moreover, the biggest issue in using conventional inorganic zinc as a feed supplement in the animal's diet is their low utilization rate, hence, animal feed manufacturers and producers used a greater amount of dietary zinc than the recommended normal requirement to achieve maximum performance of the animals [143]. The excessive addition of zinc in the feed subsequently lead to excess zinc in the excreta which causes adverse effects on the environment [144]. Apart from that, the high dietary supplement of zinc may also affect the stability of vitamins and other nutrients in the animal's body [142].

The emergence of nanotechnology associated with nanoscale has improved the bioavailability and utilization efficiency of trace elements in animal's diets [145]. Recently, ZnO NPs have been prominently studied on their effects in animal production and their potential application as a dietary supplement as an alternative to the conventional zinc [22, 142, 146, 147]. Due to their small size, $\mathrm{ZnO}$ NPs have been introduced into animal feed to increase and improve the absorption rate of zinc in the gastrointestinal tract, which would increase the uptake of zinc and bioavailability in the animal's body [19, 24]. High bioavailability of $\mathrm{ZnO}$ NPs also reduces the secretion of zinc in feces hence alleviate the environmental pollution. Apart from that, the small size of NPs would easily cross into the blood and distribute the NPs to the internal organs (Fig. 7).

The use of ZnO NPs in animal feed has been reported to enhance the growth performance of the animals. Broiler chicken was fed with diets containing 20 and 60 $\mathrm{mg} / \mathrm{kg}$ of $\mathrm{ZnO} \mathrm{NPs}$ and showed an increase in body weight gain and better feed conversion ratio compared to the use of conventional zinc [142]. However, the higher concentration of $\mathrm{ZnO}$ NPs $(100 \mathrm{mg} / \mathrm{kg})$ inhibits the growth performance which indicates that the effects of $\mathrm{ZnO}$ NPs supplementation depend on their level of concentration and should be fed at the appropriate level [142]. In another study, the dietary supplement of $\mathrm{ZnO}$ NPs at 60 and $90 \mathrm{mg} / \mathrm{kg}$ had significantly improved broiler carcass yield by increasing the live body weight, dressing and carcass weight [20]. Generally, about 2000 to $4000 \mathrm{mg} / \mathrm{kg}$ of dietary zinc supplement is added into the feed in weaning piglets in order to promote the growth performance and to prevent the occurrence of diarrhea [148]. This inclusion of excessive zinc is higher than the recommended normal requirement and therefore will increase the feed cost and cause an environmental impact. Wang et al. [22] demonstrated a feeding trial on weaned piglet using $\mathrm{ZnO}$ NPs and conventional $\mathrm{ZnO}$ plus colistin sulfate at $1200 \mathrm{mg} / \mathrm{kg}$ and $3000 \mathrm{mg} / \mathrm{kg}$, respectively. The results showed that weaned piglets 


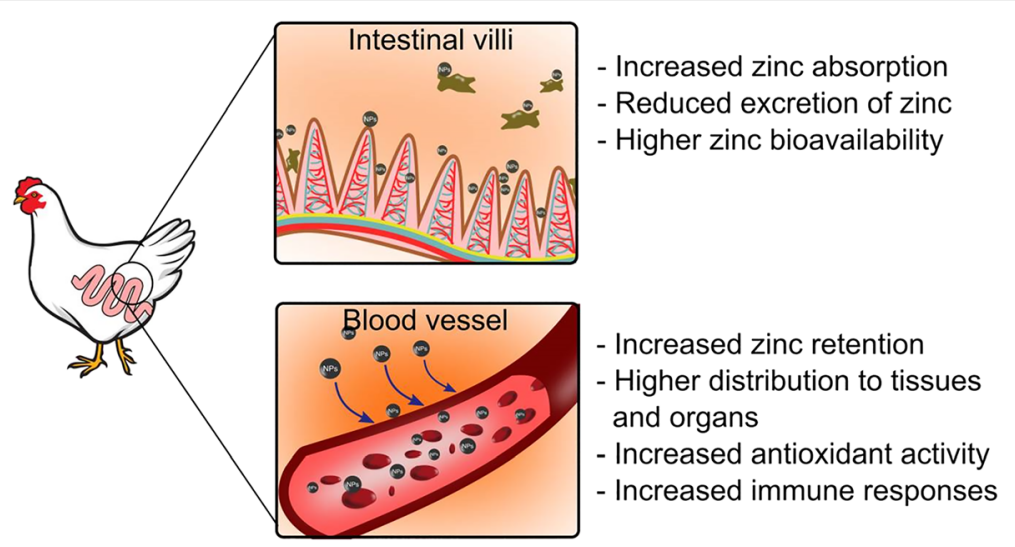

Fig. 7 Distribution of ZnO NPs in animal body. ZnO NPs has the capability to cross the gastrointestinal tract and then further distribute into the blood and into the targeted organs

supplemented with ZnO NPs had improved growth performances with alleviating diarrhea and the interestingly similar result was also reported in dietary treatment with conventional $\mathrm{ZnO}$ at higher doses. Therefore, the use of $\mathrm{ZnO}$ NPs in lower doses was found to be efficacious and can be substituted for the higher doses of conventional $\mathrm{ZnO}$ and also prevent the excretion of excessive zinc in feces into the environment.

The thin eggshell is a common problem in old layer hens which resulted in easily broken eggs. The thickness and strength of eggshell were found to be enhanced in dietary supplemented with ZnO NPs and Znmethionine compared to the conventional $\mathrm{ZnO}$. The inclusion of $\mathrm{ZnO}$ NPs in the diets also showed the highest egg production [25]. This may be attributed to the fact that the important role of zinc in the synthesis and secretion of the reproductive hormone which contributed to the high bioavailability and uptake efficiency of $\mathrm{ZnO}$ NPs for the production of eggs. In addition, the use of ZnO NPs in the study had increased the thickness of the eggshell and was found similar to the results of dietary with Zn-methionine (organic zinc) [25]. Zinc is known as a component of the carbonic anhydrase enzyme which plays an important role in the formation process of eggshell as well as in improving the strength of the eggshell [28]. In another study, the thickness of the eggshell was also found improved in layer hens supplemented with organic zinc and ZnO NPs, contributed by the high bioavailability and zinc retention in the body [24]. Therefore, supplementation of ZnO NPs in layer hens could enhance the egg's quality and solve the problem of thin eggshells in the old layers and the efficacy of ZnO NPs was found higher as organic zinc and could substitute the use of organic zinc.

In recent years, several studies have used a combination of probiotics mixed with nano minerals including selenium NPs [149] and ZnO NPs [147]. It has been suggested that probiotic has the ability to decrease the $\mathrm{pH}$ of intestine due to the modulation of gut microflora resulting in the increased of short-chain fatty acids [150] which increase the mineral solubility and absorbability [151]. A synergistic effect was observed in the dietary combination of probiotic and $\mathrm{ZnO}$ NPs on the improvement of villus height and width of broiler chicken. The results showed a better improvement of villi height to crypt depth ratio in broilers fed with ZnO NPs $(50 \mathrm{mg} /$ $\mathrm{kg})$ and probiotic compared to conventional zinc oxide and $\mathrm{ZnO}$ NPs $(25 \mathrm{mg} / \mathrm{kg})$ [147]. Intestinal morphology is important for better absorption of nutrients as larger villi enable intestine greater absorption of nutrients. Supplementation of probiotic together with $\mathrm{ZnO}$ NPs has significantly improved the intestine morphology thus provide a better absorption of other nutrients and increases the body's health. A dietary supplementation of $\mathrm{ZnO}$ NPs alone also has greater effects on the improvement of intestinal morphology. A weaned piglet was fed a basal diet supplemented with $1200 \mathrm{mg} / \mathrm{kg} \mathrm{ZnO}$ NPs showed increases in villus width, length and surface area which will provide greater absorption ability [22].

Zinc is an essential mineral which acts as a catalyst or coenzyme factors in many enzymes including superoxide dismutase (SOD). SOD acts as an essential component in the antioxidant defence system which plays a significant role in the detoxification of superoxide free radicals and protects the cells against oxidative stress [152]. Fathi et al., [27] fed $20 \mathrm{mg} / \mathrm{kg}$ of ZnO NPs to broiler chicken and showed a significant effect on copper-zincsuperoxide dismutase $(\mathrm{Cu}-\mathrm{Zn}-\mathrm{SOD})$ activity. $\mathrm{Cu}-\mathrm{Zn}$ SOD is a metalloenzyme which belongs to the ubiquitous family of SOD [153]. However, no significant effect was observed on the $\mathrm{Cu}$-Zn-SOD activity at higher concentration. In addition, greater SOD enzyme activity was found in the liver and pancreas tissue of layer hens when supplemented with $\mathrm{ZnO} \mathrm{NPs}$ at $80 \mathrm{mg} / \mathrm{kg}$ and organic 
zinc compared to the conventional zinc [25]. It has been known that the bioavailability of ZnO NPs and organic zinc is high thus lead to greater zinc retention and lower the excretion as well as increased the activity of SOD. Furthermore, catalase is also known as an antioxidant enzyme which functions to protect the cells from oxidative damage by ROS [154]. The decrease in catalase activity is related to the increase in oxidative stress [155]. In Zhao et al. [142] study, catalase activity in serum was significantly higher in broiler chicken fed with $20 \mathrm{mg} / \mathrm{kg}$ of $\mathrm{ZnO}$ NPs which indicated supplementation of $\mathrm{ZnO}$ NPs induced the antioxidant activity. However, higher supplementations of $\mathrm{ZnO}$ NPs at $100 \mathrm{mg} / \mathrm{kg}$ eventually inhibit the catalase activity in the liver tissue samples.

Zinc supplementation provides a better immune system function. Zinc is essential for thymulin to produce peripheral T-cell and thymocytes through the thymus secretion [156]. Thus, the high bioavailability of zinc contributes to the increase of thymulin activity and therefore, promotes the immune responses in the animal's body. The inclusion of $\mathrm{ZnO}$ NPs at $80 \mathrm{mg} / \mathrm{kg}$ into the diet was found to increase the sheep red blood cells (SRBC) antibody titre in layer hens compared to the conventional zinc. The higher cellular immune response to antibody titres against the Newcastle disease was also found in the diet with $\mathrm{ZnO}$ NPs [25]. In addition, a comparative study of dietary supplementation between inorganic (conventional inorganic zinc), organic (zinc-methionine) and ZnO NPs on broiler chicken found higher antibody titres against SRBC in the dietary treatment of organic and $\mathrm{ZnO}$ NPs compared to the conventional zinc [18]. This result indicates that the bioavailability of zinc in the body plays a significant role in a better immune response. In summary, zinc is one of the important trace elements in an animal body for biological functions. Numerous studies have verified the efficiency of $\mathrm{ZnO}$ NPs over conventional zinc, and what is more, the efficacy of $\mathrm{ZnO}$ NPs is better as organic zinc. Moreover, $\mathrm{ZnO} \mathrm{NPs}$ can be used as an alternative to the conventional zinc which will reduce the quantity required.

\section{Toxicological effects of ZnO NPs on animals}

Despite their potential use as a feed supplement, $\mathrm{ZnO}$ NPs also tend to cause adverse effects on animals. However, the toxicological hazards of ZnO NPs remain controversial because while a few studies have reported $\mathrm{ZnO}$ NPs to have therapeutic benefits, other studies reported their toxicity on living organisms. Nevertheless, studies have suggested that the toxicity effects of $\mathrm{ZnO}$ NPs are dependent on their concentration (dose) [157], size [158, 159], morphology, and surface composition [160]. Moreover, the toxicity mechanisms of $\mathrm{ZnO}$ NPs still remain unclear. However, it has been proposed that they can easily enter cells or bind with the membrane or release $\mathrm{Zn}^{2+}$ and generate oxidative stress-mediated
DNA damage and lipid peroxidation, which subsequently cause apoptosis $[9,67,144]$.

Several studies have reported that high doses of $\mathrm{ZnO}$ NPs supplementation could lead to toxicity [161-164]. The results of an in vivo experiment conducted by Wang et al. [162] show that the supplementation of high doses $\mathrm{ZnO}$ NPs at $5000 \mathrm{mg} / \mathrm{kg}$ caused toxicity in mice by decreasing their body's weight and increasing the relative weight of the pancreas, brain, and lung. Moreover, zinc accumulation was also observed in the liver, pancreas, kidney, and bones. Meanwhile, long-term exposure to $\mathrm{ZnO}$ NPs at 50 and $500 \mathrm{mg} / \mathrm{kg}$ only showed minimal toxicity. Furthermore, oral administration of $\mathrm{ZnO}$ NPs ( $20 \mathrm{mg} / \mathrm{kg}$ body weight) in lambs caused toxicity effects, which were increased levels of blood urea nitrogen (BUN) and creatinine, indicating renal dysfunction [163]. In the histopathological examination, a high concentration of oral administration of ZnO NPs at $400 \mathrm{mg} / \mathrm{kg}$ induced focal hemorrhages and necrosis on the liver and heart tissue of Wistar rats, which were caused by oxidative stress [165]. In another study, Wang et al. [22] carried out serum biochemical assay to determine the toxicity of lower dosage of $\mathrm{ZnO}$ NPs supplementation on weaned piglets. Enzymes such as glutamic oxaloacetic transaminase (GOT), glutamic-pyruvic transaminase (GPT), and lactate dehydrogenase (LDH) are important biological parameters to evaluate the possible toxicity in vivo. There were no effects in serum activity (GOT, GPT, LDH) in weaned piglets fed with $1200 \mathrm{mg} / \mathrm{kg} \mathrm{ZnO}$ $\mathrm{NPs}$, indicating that supplementation of $\mathrm{ZnO}$ NPs at a certain level of concentration does not lead to toxicity [22].

The toxicity effects of NPs are also associated with their sizes and shapes. The smaller NPs $(3-6 \mathrm{~nm})$ are more easily cleared out from the kidneys compared to bigger NPs (approximately $30 \mathrm{~nm}$ ), which remain in the liver [166]. Furthermore, bigger NPs also tend to stay longer in the kidneys due to the slower excretion mechanisms of glomerular filtration and this long-term retention can lead to organ toxicity [167]. In addition, different morphologies of NPs also contribute to the toxicity effects regardless of their specific surface area. Wahab et al. [168] investigated the cytotoxicity effects of $\mathrm{ZnO}$ NPs with different morphologies such as nanoplates, nanorods, nanosheet, and nanoflower on malignant human T98G gliomas and fibroblast cells. Nanorods demonstrated higher cytotoxicity and inhibitory effects on cancer and normal cells, respectively, due to a larger effective surface area that potentially induces higher oxidative stress on cells. Moreover, all aforesaid studies used chemically synthesized $\mathrm{ZnO}$ NPs, which could be one of the possible causes of the innate toxicity of NPs due to the chemical reaction conditions in the conventional method. 
Due to the accumulated scientific reports on the toxic nature of $\mathrm{ZnO} \mathrm{NPs}$, several strategies have been employed to produce safer NPs without affecting their unique physicochemical properties. Surface-bound chemical modification is a commonly used method to alter the surface of NPs which play a crucial role in their biological interactions [169]. Using this method, NPs are coated with selective substances such as silica [170, 171], organosilanes [172], chitosan [173], and polyethylene glycol [169]. Chia et al. [170] used a thin silica coating for surface modification of $\mathrm{ZnO}$ NPs, which was effective in reducing their cytotoxicity effect on epithelial cells by restricting the dissociation of $\mathrm{ZnO} N P s$ to $\mathrm{Zn}^{2+}$. However, the silica coating is not ultimately benign because high concentrations of silica-coated NPs still induced cytotoxicity to mammalian gut cells [170]. Among the coating substances, polyethylene glycol (PEG) is widely used for surface modification of NPs due to its biocompatibility and biodegradation properties [67]. Several studies have reported that PEG coating is very effective in inhibiting the toxicity of NPs by modulating the release of $\mathrm{Zn}^{2+}$ and ROS production [174]. PEGcoated $\mathrm{ZnO}$ NPs was reported to have reduced cytotoxicity on human acute leukemia cell line (THP-1) [169]. Furthermore, Martinez et al. [174] carried out a study to compare the cytotoxicity effect of PEG-coated ZnO NPs and uncoated $\mathrm{ZnO}$ NPs on breast cancer MCF-7 cell line. Cells treated with PEG-coated ZnO NPs had higher viability, which indicates that surface modification with PEG interferes with the pathways of cytotoxicity, while the uncoated ZnO NPs shows cytotoxicity on the tested cell line. Surface modification approach is potentially a great strategy in reducing the toxic hazards of NPs; however, this strategy needs to be reconsidered when considering its manufacturing cost for large-scale production. In summary, the toxicity effects of $\mathrm{ZnO}$ NPs are caused by their dosage, size, and shape; thus, the use of $\mathrm{ZnO}$ NPs in animal diets should be restricted to a specific minimum concentration to avoid their toxic effects. Moreover, for improved safety of ZnO NPs, microbemediated synthesis should be considered in NPs production due to its biocompatibility as well as controllable NPs size and shape which can be achieved through the optimization process.

\section{Conclusions and future prospects}

The biologically active compounds secreted by the microbes have dual role functional groups in reducing and stabilizing agent. The microbial synthesis process is easier, simpler and does not involve any hazardous chemicals. Nevertheless, there remain challenges in the microbes mediated synthesis to obtain the desired NPs and to produce high yield NPs. Thus, many optimization processes have been performed by varying the physicochemical parameters and the type of microbes to obtain desirable NPs as well as increase the yield, however, further investigation is needed to understand the formation mechanisms of NPs due to variation between different microbes' species.

$\mathrm{ZnO}$ NPs contain promising properties to be implemented in the poultry and livestock industry. Moreover, $\mathrm{ZnO}$ NPs exhibit potential use as the therapeutic agents due to their bactericidal effects on the wide spectrum of bacteria and fungi. As such, this can potentially replace the conventional antibiotics that tend to develop multidrug-resistant bacteria. Furthermore, the use of $\mathrm{ZnO}$ NPs as the feed supplement in the animal diet revealed a better bioavailability and high absorption rate due to to their smaller size compared to conventional inorganic zinc sources. The use of $\mathrm{ZnO}$ NPs increased the utilization rate of zinc in the body and alleviated the environmental impact by reducing the amount of zinc in the diet and thus decreased the undigested zinc in excreta.

Studies have shown that the conventional chemical and physical methods may potentially contain toxic chemical bound on the surfaces of NPs, which may cause the toxicity effects in the body. Despite having the potential application as an antimicrobial agent and nutrient component, $\mathrm{ZnO}$ NPs also tend to cause toxicity in the body. The toxicity effects could be caused by their size, shape and concentration of NPs. Nevertheless, to date, there is no data available on the use of biological mediated synthesis of ZnO NPs to be tested on the poultry and livestock feed. Thus, further investigation is needed to evaluate the effects of $\mathrm{ZnO}$ NPs that are produced using microbes to be used as a feed supplement in the diet as well as the antimicrobial agents. Moreover, microbes mediated synthesis have the ability to control and manipulate the size, shape and produce desireable NPs which would offer the advantage over chemical and physical methods. In addition, the source of $\mathrm{ZnO}$ NPs from microbial synthesis may have additional properties on their functional groups. This may enhance their chemical and biological function, where it is safe to be used in the living organisms. Furthermore, there is a need to explore more potential microbes in the synthesis of $\mathrm{ZnO}$ NPs as there are only a few potential microbes that are reported in the literature. There are diverse species of microbes in the environment; hence, it is necessary to screen novel groups of microbes. In addition, the biochemical and molecular mechanisms with regard to the synthesis mechanisms by microbes should be further elucidated. Therefore, biological synthesis of $\mathrm{ZnO}$ NPs by utilizing microbes could represent a new source of key advancements in sustainable agriculture, particularly in the animal industry. 


\section{Abbreviations}

DLS: Dynamic light scattering; FTIR: Fourier-transform infrared spectroscopy; LAB: Lactic acid bacteria; NADH: Nicotinamide adenine dinucleotide; ROS: Reaction oxygen species; SDS-PAGE: Sodium dodecyl sulphatepolyacrylamide gel electrophoresis; SEM: Scanning electron microscopy; SOD: Superoxide dismutase; TEM: Transmission electron microscopy; UVVis: Ultraviolet-visible spectroscopy; ZnO NPs: Zinc oxide nanoparticles

\section{Acknowledgements}

Not applicable.

\section{Authors' contributions}

HMY initiated the idea, the scope, and drafted this review paper. NAAR, RM and $U H Z$ were involved in the manuscript preparation and conducted the final editing and proofreading. All authors read and approved the final manuscript.

\section{Funding}

The authors extend their appreciation to Universiti Putra Malaysia (UPM) for financing this work through Putra Graduate Initiative (IPS).

\section{Availability of data and materials}

Data sharing is not applicable to this article as no datasets were generated or analysed during the current study.

\section{Ethics approval and consent to participate}

Not applicable.

\section{Consent for publication}

Not applicable.

\section{Competing interests}

The authors declare that they have no competing interests.

\section{Author details}

'Department of Bioprocess Technology, Faculty of Biotechnology and Biomolecular Sciences, Universiti Putra Malaysia, 43400 Serdang, Selangor, Malaysia. ${ }^{2}$ Bioprocessing and Biomanufacturing Research Centre, Faculty of Biotechnology and Biomolecular Sciences, Universiti Putra Malaysia, 43400 Serdang, Selangor, Malaysia. ${ }^{3}$ Department of Biochemistry, Faculty of Biotechnology and Biomolecular Sciences, Universiti Putra Malaysia, 43400 Serdang, Selangor, Malaysia.

\section{Received: 14 January 2019 Accepted: 29 May 2019}

Published online: 09 July 2019

\section{References}

1. Singh RP, Shukla VK, Yadav RS, Sharma PK, Singh PK, Pandey AC. Biological approach of zinc oxide nanoparticles formation and its characterization. Adv Mater Lett. 2011;2:313-7. https://doi.org/10.5185/ amlett.indias.204.

2. Piccinno F, Gottschalk F, Seeger S, Nowack B. Industrial production quantities and uses of ten engineered nanomaterials in Europe and the world. J Nanopart Res. 2012;14. https://doi.org/10.1007/s11051012-1109-9.

3. Sharma D, Sharma S, Kaith BS, Rajput J, Kaur M. Synthesis of ZnO nanoparticles using surfactant free in-air and microwave method. Appl Surf Sci. 2011;257:9661-72. https://doi.org/10.1016/j.apsusc.2011.06.094

4. FDA. FDA (Food and Drug Administration), Washington DC, USA, 2015. Select Committee on GRAS Substances (SCOGS) Opinion: Zinc Salts 2015. https://www.accessdata.fda.gov/scripts/cdrh/cfdocs/cfcfr/CFRSearch.cfm?fr= 182.8991. Accessed 5 Nov 2018

5. Pulit-Prociak J, Chwastowski J, Kucharski A, Banach M. Functionalization of textiles with silver and zinc oxide nanoparticles. Appl Surf Sci. 2016:385:54353. https://doi.org/10.1016/j.apsusc.2016.05.167.

6. Anbuvannan M, Ramesh M, Viruthagiri G, Shanmugam N, Kannadasan N. Synthesis, characterization and photocatalytic activity of $\mathrm{ZnO}$ nanoparticles prepared by biological method. Spectrochim Acta A Mol Biomol Spectrosc. 2015;143:304-8. https://doi.org/10.1016/j.saa.2015.01.124.
7. Patel P, Kansara K, Senapati VA, Shanker R, Dhawan A, Kumar A. Cell cycle dependent cellular uptake of zinc oxide nanoparticles in human epidermal cells. Mutagenesis. 2016. https://doi.org/10.1093/mutage/gew014.

8. Sundrarajan M, Ambika S, Bharathi K. Plant-extract mediated synthesis of $\mathrm{ZnO}$ nanoparticles using Pongamia pinnata and their activity against pathogenic bacteria. Adv Powder Technol. 2015;26:1294-9. https://doi.org/ 10.1016/j.apt.2015.07.001

9. Swain PS, Rao SBN, Rajendran D, Dominic G, Selvaraju S. Nano zinc, an alternative to conventional zinc as animal feed supplement: a review. Anim Nutr. 2016;2:134-41. https://doi.org/10.1016/j.aninu.2016.06.003.

10. Sturikova H, Krystofova O, Huska D, Adam V. Zinc, zinc nanoparticles and plants. J Hazard Mater. 2018. https://doi.org/10.1016/j.jhazmat.2018.01.040.

11. Vallee $\mathrm{BL}$, Falchuk KH. The biochemical basis of zinc physiology. Physiol Rev. 1993;73:79-118. https://doi.org/10.1152/physrev.1993.73.1.79.

12. Jamdagni $P$, Khatri $P$, Rana JS. Green synthesis of zinc oxide nanoparticles using flower extract of Nyctanthes arbor-tristis and their antifungal activity. J King Saud Univ - Sci. 2018:30:168-75. https://doi. org/10.1016/j.jksus.2016.10.002.

13. Sirelkhatim A, Mahmud S, Seeni A, Kaus NHM, Ann LC, Bakhori SKM, et al. Review on zinc oxide nanoparticles: antibacterial activity and toxicity mechanism. Nano-Micro Lett. 2015;7:219-42. https://doi.org/10. 1007/s40820-015-0040-x.

14. Moghaddam AB, Moniri M, Azizi S, Rahim RA, Ariff AB, Saad WZ, et al. Biosynthesis of $\mathrm{ZnO}$ nanoparticles by a new Pichia kudriavzevii yeast strain and evaluation of their antimicrobial and antioxidant activities. Molecules. 2017;22:1-18. https://doi.org/10.3390/molecules22060872.

15. Saravanan M, Gopinath V, Chaurasia MK, Syed A, Ameen F, Purushothaman N. Green synthesis of anisotropic zinc oxide nanoparticles with antibacterial and cytofriendly properties. Microb Pathog. 2018;115:57-63. https://doi.org/10.1016/j.micpath.2017.12.039.

16. Jayaseelan C, Rahuman AA, Kirthi AV, Marimuthu S, Santhoshkumar T, Bagavan A, et al. Novel microbial route to synthesize $\mathrm{ZnO}$ nanoparticles using Aeromonas hydrophila and their activity against pathogenic bacteria and fungi. Spectrochim Acta A Mol Biomol Spectrosc. 2012;90:78-84. https://doi.org/10.1016/j.saa.2012.01.006.

17. Ao T, Pierce JL, Pescatore AJ, Cantor AH, Dawson KA, Ford MJ, et al. Effects of feeding different concentration and forms of zinc on the performance and tissue mineral status of broiler chicks. Br Poult Sci. 2011;52:466-71. https://doi.org/10.1080/00071668.2011.588198.

18. Sahoo A, Swain R, Mishra SK. Effect of inorganic, organic and nano zinc supplemented diets on bioavailability and immunity status of broilers. Int J Adv Res. 2014;2:828-37.

19. Gangadoo S, Stanley D, Hughes RJ, Moore RJ, Chapman J. Nanoparticles in feed: Progress and prospects in poultry research. Trends Food Sci Technol. 2016. https://doi.org/10.1016/j.tifs.2016.10.013.

20. Khah MM, Ahmadi F, Amanlou H. Influence of dietary different levels of zinc oxide nano particles on the yield and quality carcass of broiler chickens during starter stage. Indian J Anim Sci. 2015;85:287-90.

21. Morales J, Cordero G, Piñeiro C, Durosoy S. Zinc oxide at low supplementation level improves productive performance and health status of piglets. J Anim Sci. 2012;90:436-8. https://doi.org/10.2527/jas.53833.

22. Wang C, Zhang L, Su W, Ying Z, He J, Zhang L, et al. Zinc oxide nanoparticles as a substitute for zinc oxide or colistin sulfate: effects on growth, serum enzymes, zinc deposition, intestinal morphology and epithelial barrier in weaned piglets. PLoS One. 2017;12. https:// doi.org/10.1371/journal.pone.0181136.

23. Cho $\mathrm{JH}$, Upadhaya SD, Kim IH. Effects of dietary supplementation of modified zinc oxide on growth performance, nutrient digestibility, blood profiles, fecal microbial shedding and fecal score in weanling pigs. Anim Sci J. 2015;86:617-23. https://doi.org/10.1111/asj.12329.

24. Tsai YH, Mao SY, Li MZ, Huang JT, Lien TF. Effects of nanosize zinc oxide on zinc retention, eggshell quality, immune response and serum parameters of aged laying hens. Anim Feed Sci Technol. 2016; 213:99-107. https://doi.org/10.1016/j.anifeedsci.2016.01.009.

25. Abedini M, Shariatmadari F, Karimi Torshizi MA, Ahmadi H. Effects of zinc oxide nanoparticles on the egg quality, immune response, zinc retention, and blood parameters of laying hens in the late phase of production. J Anim Physiol Anim Nutr (Berl). 2018;102:736-45. https:// doi.org/10.1111/jpn.12871.

26. Li MZ, Huang JT, Tsai YH, Mao SY, Fu CM, Lien TF. Nanosize of zinc oxide and the effects on zinc digestibility, growth performances, 
immune response and serum parameters of weanling piglets. Anim Sci J. 2016;87:1379-85. https://doi.org/10.1111/asj.12579.

27. Fathi M, Haydari M, Tanha T. Effects of zinc oxide nanoparticles on antioxidant status, serum enzymes activities, biochemical parameters and performance in broiler chickens. J Livest Sci Technol. 2016;4:7-13.

28. Mabe I, Rapp C, Bain MM, Nys Y. Supplementation of a corn-soybean meal diet with manganese, copper, and zinc from organic or inorganic sources improves eggshell quality in aged laying hens. Poult Sci. 2003;82:1903-13. https://doi.org/10.1093/ps/82.12.1903.

29. Raouf Hosseini M, Nasiri Sarvi M. Recent achievements in the microbial synthesis of semiconductor metal sulfide nanoparticles. Mater Sci Semicond Process. 2015;40:293-301. https://doi.org/10.1016/j.mssp.2015.06.003.

30. Kundu D, Hazra C, Chatterjee A, Chaudhari A, Mishra S. Extracellular biosynthesis of zinc oxide nanoparticles using Rhodococcus pyridinivorans NT2: multifunctional textile finishing, biosafety evaluation and in vitro drug delivery in colon carcinoma. J Photochem Photobiol B Biol. 2014;140:194204. https://doi.org/10.1016/j.jphotobiol.2014.08.001.

31. Shamsuzzaman MA, Khanam H, Aljawfi RN. Biological synthesis of ZnO nanoparticles using C. albicans and studying their catalytic performance in the synthesis of steroidal pyrazolines. Arab J Chem. 2017;10:S1530-6. https://doi.org/10.1016/j.arabjc.2013.05.004.

32. Nam KT, Kim D-W, Yoo PJ, Chiang C-Y, Meethong N, Hammond PT, et al. Virus-enabled synthesis and assembly of nanowires for lithium ion battery electrodes. Science. 2006;312:885-8. https://doi.org/10.1126/science.1122716.

33. Azizi S, Ahmad MB, Namvar F, Mohamad R. Green biosynthesis and characterization of zinc oxide nanoparticles using brown marine macroalga Sargassum muticum aqueous extract. Mater Lett. 2014;116:275-7. https://doi. org/10.1016/j.matlet.2013.11.038.

34. Happy Agarwal, Soumya Menon, Venkat Kumar S, Rajeshkumar S. Mechanistic study on antibacterial action of zinc oxide nanoparticles synthesized using green route. Chem Biol Interact 2018;286:60-70. doi: https://doi.org/10.1016/J.CBI.2018.03.008.

35. Kolodziejczak-Radzimska A, Jesionowski T. Zinc oxide-from synthesis to application: a review. Materials (Basel). 2014. https://doi.org/10.3390/ ma7042833

36. Naveed UI Haq A, Nadhman A, Ullah I, Mustafa G, Yasinzai M, Khan I. Synthesis approaches of zinc oxide nanoparticles: the dilemma of ecotoxicity. J Nanomater. 2017. https://doi.org/10.1155/2017/8510342.

37. Ju D, Xu H, Qiu Z, Guo J, Zhang J, Cao B. Highly sensitive and selective triethylamine-sensing properties of nanosheets directly grown on ceramic tube by forming $\mathrm{NiO} / \mathrm{ZnO}$ PN heterojunction. Sensors Actuators B Chem. 2014. https://doi.org/10.1016/j.snb.2014.04.029.

38. Mclaren A, Valdes-Solis T, Li G, Tsang SC. Shape and size effects of ZnO nanocrystals on photocatalytic activity. J Am Chem Soc. 2009. https://doi. org/10.1021/ja9052703.

39. Aboulaich A, Balan L, Ghanbaja J, Medjahdi G, Merlin C, Schneider R. Aqueous route to biocompatible $\mathrm{ZnSe:Mn/ZnO} \mathrm{core/shell} \mathrm{quantum} \mathrm{dots}$ using 1-thioglycerol as stabilizer. Chem Mater. 2011. https://doi.org/10.1021/ cm2012928.

40. Nagvenkar AP, Deokar A, Perelshtein I, Gedanken A. A one-step sonochemical synthesis of stable ZnO-PVA nanocolloid as a potential biocidal agent. J Mater Chem B. 2016. https://doi.org/10.1039/c6tb00033a.

41. Chandrasekaran P, Viruthagiri G, Srinivasan N. The effect of various capping agents on the surface modifications of sol-gel synthesised ZnO nanoparticles. J Alloys Compd. 2012. https://doi.org/10.1016/j.jallcom.2012.06.032.

42. Gopinath K, Karthika V, Gowri S, Senthilkumar V, Kumaresan S, Arumugam A. Antibacterial activity of ruthenium nanoparticles synthesized using Gloriosa superba L. leaf extract. J Nanostructure Chem. 2014;4:83. https://doi.org/10. 1007/s40097-014-0083-4

43. Basnet $P$, Inakhunbi Chanu T, Samanta D, Chatterjee S. A review on biosynthesized zinc oxide nanoparticles using plant extracts as reductants and stabilizing agents. J Photochem Photobiol B Biol. 2018;183:201-21. https:// doi.org/10.1016/j.jphotobiol.2018.04.036

44. Ahmed S, Annu CSA, Ikram S. A review on biogenic synthesis of ZnO nanoparticles using plant extracts and microbes: a prospect towards green chemistry. J Photochem Photobiol B Biol. 2017;166:272-84. https://doi.org/ 10.1016/j.jphotobiol.2016.12.011.

45. Ovais M, Khalil AT, Islam NU, Ahmad I, Ayaz M, Saravanan M, et al. Role of plant phytochemicals and microbial enzymes in biosynthesis of metallic nanoparticles. Appl Microbiol Biotechnol. 2018:1-16. https://doi.org/10.1007/ s00253-018-9146-7.
46. Singh P, Kim YJ, Zhang D, Yang DC. Biological synthesis of nanoparticles from plants and microorganisms. Trends Biotechnol. 2016;34:588-99. https:// doi.org/10.1016/j.tibtech.2016.02.006.

47. Tripathi RM, Bhadwal AS, Gupta RK, Singh P, Shrivastav A, Shrivastav BR. ZnO nanoflowers: novel biogenic synthesis and enhanced photocatalytic activity. J Photochem Photobiol B Biol. 2014;141:288-95. https://doi.org/10.1016/j. jphotobiol.2014.10.001

48. Taran M, Rad M, Alavi M. Biosynthesis of TiO2and ZnO nanoparticles by Halomonas elongata IBRC-M 10214 in different conditions of medium. Biolmpacts. 2018;8:81-9. https://doi.org/10.15171/bi.2018.10.

49. Al-Zahrani H, El-Waseif A, El-Ghwas D. Biosynthesis and evaluation of TiO2 and $\mathrm{ZnO}$ nanoparticles from in vitro stimulation of Lactobacillus johnsonii. J Innov Pharm Biol Sci. 2018:5:16-20.

50. Król A, Railean-Plugaru V, Pomastowski P, Złoch M, Buszewski B. Mechanism study of intracellular zinc oxide nanocomposites formation. Colloids Surf A Physicochem Eng Asp. 2018;553:349-58. https://doi.org/10.1016/j.colsurfa. 2018.05.069

51. Selvarajan E, Mohanasrinivasan V. Biosynthesis and characterization of ZnO nanoparticles using lactobacillus plantarum VITES07. Mater Lett. 2013;112: 180-2. https://doi.org/10.1016/j.matlet.2013.09.020.

52. Prasad K, Jha AK. ZnO nanoparticles: synthesis and adsorption study. Nat Sci. 2009;01:129-35. https://doi.org/10.4236/ns.2009.12016.

53. Mishra M, Paliwal JS, Singh SK, Selvarajan E, Subathradevi C, Mohanasrinivasan V. Studies on the inhibitory activity of biologically synthesized and characterized zinc oxide nanoparticles using lactobacillus sporogens against Staphylococcus aureus. J Pure Appl Microbiol. 2013;7:1263-8.

54. Singh BN, Rawat AKS, Khan W, Naqvi AH, Singh BR. Biosynthesis of stable antioxidant ZnO nanoparticles by Pseudomonas aeruginosa rhamnolipids. PLoS One. 2014;9. https://doi.org/10.1371/journal.pone.0106937.

55. Rajabairavi N, Raju CS, Karthikeyan C, Varutharaju K, Nethaji S, Hameed ASH, et al. Biosynthesis of novel zinc oxide nanoparticles (ZnO NPs) using endophytic bacteria Sphingobacterium thalpophilum. Springer Proc Phys. 2017;189:245-54. https://doi.org/10.1007/978-3-319-44890-9_23.

56. Rauf MA, Owais M, Rajpoot R, Ahmad F, Khan N, Zubair S. Biomimetically synthesized ZnO nanoparticles attain potent antibacterial activity against less susceptible: S. aureus skin infection in experimental animals. RSC Adv. 2017;7:36361-73. https://doi.org/10.1039/c7ra05040b.

57. Balraj B, Senthilkumar N, Siva C, Krithikadevi R, Julie A, Potheher IV, et al. Synthesis and characterization of zinc oxide nanoparticles using marine Streptomyces sp. with its investigations on anticancer and antibacterial activity. Res Chem Intermed. 2017;43:2367-76. https://doi.org/10.1007/ s11164-016-2766-6.

58. Sarkar J, Ghosh M, Mukherjee A, Chattopadhyay D, Acharya K. Biosynthesis and safety evaluation of ZnO nanoparticles. Bioprocess Biosyst Eng. 2014;37: 165-71. https://doi.org/10.1007/s00449-013-0982-7.

59. Jain N, Bhargava A, Tarafdar JC, Singh SK, Panwar J. A biomimetic approach towards synthesis of zinc oxide nanoparticles. Appl Microbiol Biotechnol. 2013;97:859-69. https://doi.org/10.1007/s00253-012-3934-2.

60. Rajan A, Cherian E, Baskar G. Biosynthesis of zinc oxide nanoparticles using Aspergillus fumigatus JCF and its antibacterial activity. Int J Mod Sci Technol. 2016;1:52-7.

61. Raliya R, Tarafdar JC. ZnO nanoparticle biosynthesis and its effect on phosphorous-mobilizing enzyme secretion and gum contents in cluster bean (Cyamopsis tetragonoloba L.). Agric Res. 2013;2:48-57. https://doi.org/ 10.1007/s40003-012-0049-z.

62. Kalpana VN, Kataru BAS, Sravani N, Vigneshwari T, Panneerselvam A, Devi Rajeswari V. Biosynthesis of zinc oxide nanoparticles using culture filtrates of Aspergillus niger: antimicrobial textiles and dye degradation studies. OpenNano. 2018;3:48-55. https://doi.org/10.1016/j.onano.2018.06.001.

63. Baskar G, Chandhuru J, Fahad KS, Praveen AS. Mycological Synthesis, Characterization and antifungal activity of zinc oxide nanoparticles. Asian J Pharm Technol. 2013:3:142-6.

64. Velmurugan P, Shim J, You Y, Choi S, Kamala-Kannan S, Lee KJ, et al. Removal of zinc by live, dead, and dried biomass of Fusarium spp. isolated from the abandoned-metal mine in South Korea and its perspective of producing nanocrystals. J Hazard Mater. 2010;182:317-24. https://doi.org/10. 1016/j.jhazmat.2010.06.032.

65. Chauhan R, Reddy A, Abraham J. Biosynthesis of silver and zinc oxide nanoparticles using Pichia fermentans JA2 and their antimicrobial property. Appl Nanosci. 2015;5:63-71. https://doi.org/10.1007/s13204014-0292-7 
66. Kitching M, Ramani M, Marsili E. Fungal biosynthesis of gold nanoparticles: mechanism and scale up. Microb Biotechnol. 2015;8:904-17. https://doi.org/ 10.1111/1751-7915.12151.

67. Król A, Pomastowski P, Rafińska K, Railean-Plugaru V, Buszewski B. Zinc oxide nanoparticles: synthesis, antiseptic activity and toxicity mechanism. Adv Colloid Interf Sci. 2017;249:37-52. https://doi.org/10.1016/j.cis.2017.07.033.

68. Giller KE, Witter E, McGrath SP. Heavy metals and soil microbes. Soil Biol Biochem. 2009;41:2031-7. https://doi.org/10.1016/j.soilbio.2009.04.026.

69. Salvadori MR, Ando RA, Oller Do Nascimento CA, Corrêa B. Intracellular biosynthesis and removal of copper nanoparticles by dead biomass of yeast isolated from the wastewater of a mine in the Brazilian Amazonia. PLoS One. 2014;9. https://doi.org/10.1371/journal.pone.0087968.

70. Pócsi I. Toxic metal/metalloid tolerance in fungi---a biotechnology-oriented approach. In: Banfalvi G, editor. Cell. Eff. Heavy met. Dordrecht: Springer Netherlands; 2011. p. 31-58. https://doi.org/10.1007/978-94-007-0428-2_2.

71. Bhargava A, Jain N, Khan MA, Pareek V, Dilip RV, Panwar J. Utilizing metal tolerance potential of soil fungus for efficient synthesis of gold nanoparticles with superior catalytic activity for degradation of rhodamine B. J Environ Manag. 2016;183:22-32. https://doi.org/10.1016/j.jenvman.2016. 08.021.

72. Velusamy P, Kumar GV, Jeyanthi V, Das J, Pachaiappan R. Bio-inspired green nanoparticles: synthesis, mechanism, and antibacterial application. Toxicol Res. 2016;32:95-102. https://doi.org/10.5487/TR.2016.32.2.095.

73. Chapot-Chartier MP, Kulakauskas S. Cell wall structure and function in lactic acid bacteria. Microb Cell Factories. 2014. https://doi.org/10.1186/1475-285913-S1-S9.

74. Korbekandi H, Iravani S, Abbasi S. Optimization of biological synthesis of silver nanoparticles using Lactobacillus casei subsp. casei. J Chem Technol Biotechnol. 2012;87:932-7. https://doi.org/10.1002/jctb.3702.

75. Sastry M, Ahmad A, Islam Khan M, Kumar R. Biosynthesis of metal nanoparticles using fungi and actinomycete. Curr Sci. 2003;85:162-70. https://doi.org/10.1016/S0927-7765(02)00174-1.

76. Markus J, Mathiyalagan R, Kim YJ, Abbai R, Singh P, Ahn S, et al. Intracellular synthesis of gold nanoparticles with antioxidant activity by probiotic Lactobacillus kimchicus DCY51T isolated from Korean kimchi. Enzym Microb Technol. 2016;95:85-93. https://doi.org/10.1016/j.enzmictec.2016.08.018.

77. Slavin YN, Asnis J, Häfeli UO, Bach H. Metal nanoparticles: understanding the mechanisms behind antibacterial activity. J Nanobiotechnology. 2017. https://doi.org/10.1186/s12951-017-0308-z.

78. Zhang X, Yan S, Tyagi RD, Surampalli RY. Synthesis of nanoparticles by microorganisms and their application in enhancing microbiological reaction rates. Chemosphere. 2011;82:489-94. https://doi.org/10.1016/j.chemosphere. 2010.10.023

79. Iravani S. Bacteria in nanoparticle synthesis: current status and future prospects. Int Sch Res Not. 2014;2014:1-18. https://doi.org/10.1155/2014/ 359316.

80. Shedbalkar U, Singh R, Wadhwani S, Gaidhani S, Chopade BA. Microbial synthesis of gold nanoparticles: current status and future prospects. Adv Colloid Interf Sci. 2014;209:40-8. https://doi.org/10. 1016/j.cis.2013.12.011

81. Mukherjee P, Ahmad A, Mandal D, Senapati S, Sainkar SR, Khan MI, et al. Bioreduction of AuCl4-ions by the fungus, Verticillium sp. and surface trapping of the gold nanoparticles formed. Angew Chemie Int Ed. 2001;40: 3585-8. https://doi.org/10.1002/1521-3773(20011001)40:19<3585::AIDANIE3585>3.0.CO;2-K

82. Ahmad A, Senapati S, Khan MI, Kumar R, Ramani R, Srinivas V, et al. Intracellular synthesis of gold nanoparticles by a novel alkalotolerant actinomycete, Rhodococcus species. Nanotechnology. 2003;14:824-8. https://doi.org/10.1088/0957-4484/14/7/323.

83. Alamri SA, Hashem MA, Nafady NA, Sayed MA, Alshehri AA, El-Alshaboury GA. Controllable biogenic synthesis of intracellular silver/silver chloride nanoparticles by Meyerozyma guilliermondii KX008616. J Microbiol Biotechnol. 2018;28:917-30. https://doi.org/10.4014/jmb.1802.02010.

84. Konishi Y, Tsukiyama T, Tachimi T, Saitoh N, Nomura T, Nagamine S. Microbial deposition of gold nanoparticles by the metal-reducing bacterium Shewanella algae. Electrochim Acta. 2007;53:186-92. https://doi.org/10.1016/ j.electacta.2007.02.073.

85. Anil Kumar S, Abyaneh MK, Gosavi SW, Kulkarni SK, Pasricha R, Ahmad $\mathrm{A}$, et al. Nitrate reductase-mediated synthesis of silver nanoparticles from $\mathrm{AgNO}_{3}$. Biotechnol Lett. 2007:29:439-45. https://doi.org/10.1007/ s10529-006-9256-7.
86. Durán N, Marcato PD, Alves OL, De GlH, Esposito E. Mechanistic aspects of biosynthesis of silver nanoparticles by several Fusarium oxysporum strains. J Nanobiotechnology. 2005;7:1-7. https://doi.org/10.1186/1477-3155-3-8.

87. Kalimuthu K, Suresh Babu R, Venkataraman D, Bilal M, Gurunathan S. Biosynthesis of silver nanocrystals by Bacillus licheniformis. Colloids Surf B Biointerfaces. 2008;65:150-3. https://doi.org/10.1016/j.colsurfb.2008.02.018.

88. Hulkoti NI, Taranath TC. Biosynthesis of nanoparticles using microbes-a review. Colloids Surf B Biointerfaces. 2014;121:474-83. https://doi.org/10. 1016/j.colsurfb.2014.05.027.

89. Jain N, Bhargava A, Majumdar S, Tarafdar JC, Panwar J. Extracellular biosynthesis and characterization of silver nanoparticles using Aspergillus flavusNJP08: a mechanism perspective. Nanoscale. 2011;3:635-41. https:// doi.org/10.1039/CONR00656D.

90. Tugarova AV, Kamnev AA. Proteins in microbial synthesis of selenium nanoparticles. Talanta. 2017;174:539-47. https://doi.org/10.1016/j.talanta. 2017.06.013

91. Wadhwani SA, Shedbalkar UU, Singh R, Chopade BA. Biosynthesis of gold and selenium nanoparticles by purified protein from Acinetobacter sp. SW 30. Enzym Microb Technol. 2018;111:81-6. https://doi.org/10.1016/j. enzmictec.2017.10.007

92. Sneha K, Sathishkumar M, Mao J, Kwak IS, Yun YS. Corynebacterium glutamicum-mediated crystallization of silver ions through sorption and reduction processes. Chem Eng J. 2010;162:989-96. https://doi.org/10.1016/j. cej.2010.07.006.

93. Bao $H$, Hao N, Yang Y, Zhao D. Biosynthesis of biocompatible cadmium telluride quantum dots using yeast cells. Nano Res. 2010;3:481-9. https:// doi.org/10.1007/s12274-010-0008-6.

94. Sadeghi B, Garmaroudi FS, Hashemi M, Nezhad HR, Nasrollahi A, Ardalan S, et al. Comparison of the anti-bacterial activity on the nanosilver shapes: nanoparticles, nanorods and nanoplates. Adv Powder Technol. 2012;23:22-6. https://doi.org/10.1016/j.apt.2010.11.011

95. Raghupathi KR, Koodali RT, Manna AC. Size-dependent bacterial growth inhibition and mechanism of antibacterial activity of zinc oxide nanoparticles. Langmuir. 2011;27:4020-8. https://doi.org/10.1021/la104825u.

96. Verma A, Mehata MS. Controllable synthesis of silver nanoparticles using neem leaves and their antimicrobial activity. J Radiat Res Appl Sci. 2016;9: 109-15. https://doi.org/10.1016/j.jrras.2015.11.001.

97. Gericke M, Pinches A. Microbial production of gold nanoparticles. Gold Bull. 2006;39:22-8. https://doi.org/10.1007/BF03215529.

98. Gurunathan S, Kalishwaralal K, Vaidyanathan R, Venkataraman D, Pandian SRK, Muniyandi J, et al. Biosynthesis, purification and characterization of silver nanoparticles using Escherichia coli. Colloids Surf B Biointerfaces. 2009: 74:328-35. https://doi.org/10.1016/j.colsurfb.2009.07.048.

99. Ma L, Su W, Liu JX, Zeng XX, Huang Z, Li W, et al. Optimization for extracellular biosynthesis of silver nanoparticles by Penicillium aculeatum Su1 and their antimicrobial activity and cytotoxic effect compared with silver ions. Mater Sci Eng C. 2017;77:963-71. https://doi.org/10.1016/j.msec. 2017.03.294

100. Mohammed Fayaz A, Balaji K, Kalaichelvan PT, Venkatesan R. Fungal based synthesis of silver nanoparticles-an effect of temperature on the size of particles. Colloids Surf B Biointerfaces. 2009;74:123-6. https://doi.org/10. 1016/j.colsurfb.2009.07.002.

101. Saxena J, Sharma PK, Sharma MM, Singh A, Fu Y, Mathew J, et al. Process optimization for green synthesis of silver nanoparticles by Sclerotinia sclerotiorum MTCC 8785 and evaluation of its antibacterial properties. SpringerPlus. 2016;423:63-8. https://doi.org/10.1016/J.COLSURFA.2013.01.059.

102. Ong CB, Ng LY, Mohammad AW. A review of $\mathrm{ZnO}$ nanoparticles as solar photocatalysts: synthesis, mechanisms and applications. Renew Sust Energ Rev. 2018;81:536-51. https://doi.org/10.1016/j.rser.2017.08.020.

103. Jiang J, Pi J, Cai J. The advancing of zinc oxide nanoparticles for biomedical applications. Bioinorg Chem Appl. 2018;18. https://doi.org/10.1155/2018/1062562.

104. Lu PJ, Huang SC, Chen YP, Chiueh LC, Shih DYC. Analysis of titanium dioxide and zinc oxide nanoparticles in cosmetics. J Food Drug Anal. 2015; 23:587-94. https://doi.org/10.1016/j.jfda.2015.02.009.

105. Rajalakshmi M, Sohila S, Ramya S, Divakar R, Ghosh C, Kalavathi S. Blue green and UV emitting $\mathrm{ZnO}$ nanoparticles synthesized through a nonaqueous route. Opt Mater (Amst). 2012;34:1241-5. https://doi.org/10.1016/j. optmat.2012.01.021.

106. Sabir S, Arshad M, Chaudhari SK. Zinc oxide nanoparticles for revolutionizing agriculture: synthesis and applications. Sci World J. 2014;2014. https://doi. org/10.1155/2014/925494. 
107. Zalewski PD, Truong-Tran AQ, Grosser D, Jayaram L, Murgia C, Ruffin RE. Zinc metabolism in airway epithelium and airway inflammation: basic mechanisms and clinical targets. A review. Pharmacol Ther. 2005;105:12749. https://doi.org/10.1016/j.pharmthera.2004.09.004.

108. Colon G, Ward BC, Webster TJ. Increased osteoblast and decreased Staphylococcus epidermidis functions on nanophase $\mathrm{ZnO}$ and $\mathrm{TiO}_{2}$. J Biomed Mater Res - Part A. 2006;78:595-604. https://doi.org/10.1002/jbm.a. 30789.

109. Durso LM, Cook KL. Impacts of antibiotic use in agriculture: what are the benefits and risks? Curr Opin Microbiol. 2014;19:37-44. https://doi.org/10. 1016/j.mib.2014.05.019.

110. Seil JT, Webster TJ. Antimicrobial applications of nanotechnology: methods and literature. Int J Nanomedicine. 2012;7:2767-81. https://doi.org/10.2147/ IJN.S24805.

111. Zhang L, Jiang $Y$, Ding $Y$, Povey M, York D. Investigation into the antibacterial behaviour of suspensions of $\mathrm{ZnO}$ nanoparticles ( $\mathrm{ZnO}$ nanofluids). J Nanopart Res. 2007;9:479-89. https://doi.org/10.1007/s11051006-9150-1.

112. Gomaa EZ. Synergistic antibacterial efficiency of Bacteriocin and silver nanoparticles produced by probiotic Lactobacillus paracasei against multidrug resistant bacteria. Int J Pept Res Ther. 2018. https://doi.org/10. 1007/s10989-018-9759-9.

113. Patil SD, Sharma R, Bhattacharyya T, Kumar P, Gupta M, Chaddha BS, et al. Antibacterial potential of a small peptide from Bacillus sp. RPT-0001 and its capping for green synthesis of silver nanoparticles. J Microbiol. 2015 https://doi.org/10.1007/s12275-015-4686-3.

114. Fahim HA, Khairalla AS, El-Gendy AO. Nanotechnology: a valuable strategy to improve bacteriocin formulations. Front Microbiol. 2016. https://doi.org/ 10.3389/fmicb.2016.01385.

115. Mossallam SF, Amer El, Diab RG. Potentiated anti-microsporidial activity of Lactobacillus acidophilus $\mathrm{CH} 1$ bacteriocin using gold nanoparticles. Exp Parasitol. 2014. https://doi.org/10.1016/j.exppara.2014.06.002.

116. Pandit R, Rai M, Santos CA. Enhanced antimicrobial activity of the foodprotecting nisin peptide by bioconjugation with silver nanoparticles. Environ Chem Lett. 2017;15:443-52. https://doi.org/10.1007/s10311-017-0626-2.

117. Soren S, Kumar S, Mishra S, Jena PK, Verma SK, Parhi P. Evaluation of antibacterial and antioxidant potential of the zinc oxide nanoparticles synthesized by aqueous and polyol method. Microb Pathog. 2018;119:14551. https://doi.org/10.1016/j.micpath.2018.03.048.

118. Chang Y-N, Zhang M, Xia L, Zhang J, Xing G. The toxic effects and mechanisms of $\mathrm{CuO}$ and ZnO nanoparticles. Materials (Basel). 2012;5:285071. https://doi.org/10.3390/ma5122850.

119. Xia T, Kovochich M, Liong M, Mädler L, Gilbert B, Shi H, et al. Comparison of the mechanism of toxicity of zinc oxide and cerium oxide nanoparticles based on dissolution and oxidative stress properties. ACS Nano. 2008;2: 2121-34. https://doi.org/10.1021/nn800511k

120. Lynne AM, Dorsey LL, David DE, Foley SL. Characterisation of antibiotic resistance in host-adapted salmonella enterica. Int J Antimicrob Agents. 2009:34:169-72. https://doi.org/10.1016/j.ijantimicag.2009.02.018.

121. Meunier M, Guyard-Nicodème M, Vigouroux E, Poezevara T, Béven V, Quesne $\mathrm{S}$, et al. A DNA prime/protein boost vaccine protocol developed against campylobacter jejuni for poultry. Vaccine. 2018;36:2119-25. https:// doi.org/10.1016/j.vaccine.2018.03.004.

122. European Food Safety Authority and European Centre for Disease Prevention and Control. The European Union summary report on trends and sources of zoonsoes, zoonotic agents and food-borne outbreaks in 2015. EFSA J. 2016;14:4634-864. https://doi.org/10.2903/j.efsa.2015.4329.

123. Rouger A, Tresse $\mathrm{O}$, Zagorec M. Bacterial contaminants of poultry meat: sources, species, and dynamics. Microorganisms. 2017;5:50. https://doi.org/ 10.3390/microorganisms5030050

124. Smith TC. Livestock-associated Staphylococcus aureus: the United States experience. PLoS Pathog. 2015;11. https://doi.org/10.1371/journal.ppat.1004564.

125. Foster TJ. Antibiotic resistance in Staphylococcus aureus. Current status and future prospects. FEMS Microbiol Rev. 2017:41:430-49. https://doi.org/10. 1093/femsre/fux007

126. Fasenko GM, O'Dea EE. Evaluating broiler growth and mortality in chicks with minor navel conditions at hatching. Poult Sci. 2008;87:594-7. https:// doi.org/10.3382/ps.2007-00352

127. Khatami M, Alijani HQ, Heli H, Sharifi I. Rectangular shaped zinc oxide nanoparticles: green synthesis by stevia and its biomedical efficiency. Ceram Int. 2018;44:15596-602. https://doi.org/10.1016/j.ceramint.2018.05.224.
128. Jiang W, Mashayekhi $H$, Xing B. Bacterial toxicity comparison between nanoand micro-scaled oxide particles. Environ Pollut. 2009;157:1619-25. https:// doi.org/10.1016/j.envpol.2008.12.025.

129. Vila-Donat $P$, Marín $S$, Sanchis $V$, Ramos AJ. A review of the mycotoxin adsorbing agents, with an emphasis on their multi-binding capacity, for animal feed decontamination. Food Chem Toxicol. 2018;114:246-59. https:// doi.org/10.1016/j.fct.2018.02.044.

130. Kosicki R, Błajet-Kosicka A, Grajewski J, Twaruzek M. Multiannual mycotoxin survey in feed materials and feedingstuffs. Anim Feed Sci Technol. 2016;215: 165-80. https://doi.org/10.1016/j.anifeedsci.2016.03.012.

131. Wajiha QNA, Afridi R. Comparative analysis of egg adapted vaccines and salinomycin against coccidiosis in chicks. Microb Pathog. 2018;123:454-60. https://doi.org/10.1016/J.MICPATH.2018.08.005

132. Dkhil MA, Al-Quraishy S, Wahab R. Anticoccidial and antioxidant activities of zinc oxide nanoparticles on Eimeria papillata-induced infection in the jejunum. Int J Nanomedicine. 2015;10:1961-8. https://doi.org/10.2147/IJN. S79944.

133. Feng Y, Min L, Zhang W, Liu J, Hou Z, Chu M, et al. Zinc oxide nanoparticles influence microflora in ileal digesta and correlate well with blood metabolites. Front Microbiol. 2017. https://doi.org/10.3389/fmicb.2017. 00992.

134. Yausheva E, Miroshnikov S, Sizova E. Intestinal microbiome of broiler chickens after use of nanoparticles and metal salts. Environ Sci Pollut Res. 2018. https://doi.org/10.1007/s11356-018-1991-5.

135. Jiao J, Wu J, Zhou C, Tang S, Wang M, Tan Z. Composition of ileal bacterial community in grazing goats varies across non-rumination, transition and rumination stages of life. Front Microbiol. 2016. https://doi.org/10.3389/ fmicb.2016.01364.

136. Feng Y, Gong J, Yu H, Jin Y, Zhu J, Han Y. Identification of changes in the composition of ileal bacterial microbiota of broiler chickens infected with Clostridium perfringens. Vet Microbiol. 2010. https://doi.org/10.1016/j.vetmic. 2009.07.001

137. Xia T, Ma X, Zhang L, Han M, Han M, Lai W. Dietary ZnO nanoparticles alters intestinal microbiota and inflammation response in weaned piglets. Oncotarget. 2017;8. https://doi.org/10.18632/oncotarget.17612.

138. Milani NC, Sbardella M, Ikeda NY, Arno A, Mascarenhas BC, Miyada VS. Dietary zinc oxide nanoparticles as growth promoter for weanling pigs. Anim Feed SCi Technol. 2017. https://doi.org/10.1016/j.anifeedsci.2017.03.001.

139. Wedekind KJ, Hortin AE, Baker DH. Methodology for assessing zinc bioavailability: efficacy estimates for zinc-methionine, zinc sulfate, and zinc oxide. J Anim Sci. 1992;70:178-87. https://doi.org/10.2527/1992.701178x.

140. Khoobbakht Z, Mohammadi M, Mehr MRA, Mohammadghasemi F, Sohani MM. Comparative effects of zinc oxide, zinc oxide nanoparticle and zinc-methionine on hatchability and reproductive variables in male Japanese quail. Anim Reprod Sci. 2018. https://doi.org/10.1016/j. anireprosci.2018.02.017.

141. Schlegel P, Sauvant D, Jondreville C. Bioavailability of zinc sources and their interaction with phytates in broilers and piglets. Animal. 2013;7:47-59. https://doi.org/10.1017/S1751731112001000.

142. Zhao C, Tan S-X, Xiao X, QIU X-S, Pan J-Q, Tang Z-X. Effects of dietary zinc oxide nanoparticles on growth performance and Antioxidative status in broilers. Biol Trace Elem Res. 2014;160:361-7. https://doi.org/10.1007/s12011014-0052-2.

143. Bratz K, Gölz G, Riedel C, Janczyk P, Nöckler K, Alter T. Inhibitory effect of high-dosage zinc oxide dietary supplementation on campylobacter coli excretion in weaned piglets. J Appl Microbiol. 2013;115:1194-202. https://doi.org/10.1111/jam.12307.

144. Rajput VD, Minkina TM, Behal A, Sushkova SN, Mandzhieva S, Singh R, et al. Effects of zinc-oxide nanoparticles on soil, plants, animals and soil organisms: a review. Environ Nanotechnol Monit Manag. 2018;9:76-84. https://doi.org/10.1016/j.enmm.2017.12.006.

145. Gopi M, Pearlin B, Kumar RD, Shanmathy M, Prabakar G. Role of nanoparticles in animal and poultry nutrition: modes of action and applications in formulating feed additives and food processing. Int $J$ Pharmacol. 2017;13:724-31. https://doi.org/10.3923/ijp.2017.724.731.

146. Abedini M, Shariatmadari F, Torshizi MAK, Ahmadi $\mathrm{H}$. Effects of a dietary supplementation with zinc oxide nanoparticles, compared to zinc oxide and zinc methionine, on performance, egg quality, and zinc status of laying hens. Livest Sci. 2017;203:30-6. https://doi.org/10.1016/j.livsci.2017.06.010.

147. Khajeh Bami M, Afsharmanesh M, Salarmoini M, Tavakoli H. Effect of zinc oxide nanoparticles and Bacillus coagulans as probiotic on growth, 
histomorphology of intestine, and immune parameters in broiler chickens. Comp Clin Path. 2018;27:399-406. https://doi.org/10.1007/ s00580-017-2605-1.

148. Pluske JR, Hampson DJ, Williams IH. Factors influencing the structure and function of the small intestine in the weaned pig: a review. Livest Prod Sci. 1997:51:215-36. https://doi.org/10.1016/50301-6226(97)00057-2.

149. Saleh AA. Effect of dietary mixture of aspergillus probiotic and selenium nano-particles on growth, nutrient digestibilities, selected blood parameters and muscle fatty acid profile in broiler chickens. Anim Sci Pap Reports. 2014;32:65-79.

150. Jiang SM, Jia L, Zhang MH. Probiotic and lactulose: influence on gastrointestinal flora and ph value in minimal hepatic encephalopathy rats. Int J Clin Exp Med. 2015;8:9996-10000.

151. Byrne CS, Chambers ES, Morrison DJ, Frost G. The role of short chain fatty acids in appetite regulation and energy homeostasis. Int J Obes. 2015;39: 1331-8. https://doi.org/10.1038/ijo.2015.84

152. Prasad AS. Zinc: An antioxidant and anti-inflammatory agent: role of zinc in degenerative disorders of aging. J Trace Elem Med Biol. 2014;28:364-71. https://doi.org/10.1016/j.jtemb.2014.07.019.

153. Perera NCN, Godahewa Gl, Lee J. Copper-zinc-superoxide dismutase (CuZnSOD), an antioxidant gene from seahorse (Hippocampus abdominalis); molecular cloning, sequence characterization, antioxidant activity and potential peroxidation function of its recombinant protein. Fish Shellfish Immunol. 2016;57:386-99. https://doi.org/10.1016/j.fsi.2016.08.052.

154. Jiang Z, Lin Y, Zhou G, Luo L, Jiang S, Chen F. Effects of dietary selenomethionine supplementation on growth performance, meat quality and antioxidant property in yellow broilers. J Agric Food Chem. 2009;57: 9769-72. https://doi.org/10.1021/jf902411c.

155. Duzguner V, Kaya S. Effect of zinc on the lipid peroxidation and the antioxidant defense systems of the alloxan-induced diabetic rabbits. Free Radic Biol Med. 2007;42:1481-6. https://doi.org/10.1016/j.freeradbiomed. 2007.02.021

156. Bonaventura $\mathrm{P}$, Benedetti $G$, Albarède F, Miossec P. Zinc and its role in immunity and inflammation. Autoimmun Rev. 2015;14:277-85. https://doi. org/10.1016/j.autrev.2014.11.008.

157. Deng XY, Luan QX, Chen WT, Wang YL, Wu MH, Zhang HJ, et al. Nanosized zinc oxide particles induce neural stem cell apoptosis. Nanotechnology. 2009;20. doi: Artn 115101\r. https://doi.org/10.1088/0957-4484/20/11/ 115101

158. Hanley C, Layne J, Punnoose A, Reddy KM, Coombs I, Coombs A, et al. Preferential killing of cancer cells and activated human T cells using $\mathrm{ZnO}$ nanoparticles. Nanotechnology. 2008;19:10. https://doi.org/10.1088/09574484/19/29/295103.

159. Guo D, Wu C, Jiang H, Li Q, Wang X, Chen B. Synergistic cytotoxic effect of different sized $\mathrm{ZnO}$ nanoparticles and daunorubicin against leukemia cancer cells under UV irradiation. J Photochem Photobiol B Biol. 2008;93:119-26. https://doi.org/10.1016/j.jphotobiol.2008.07.009.

160. Pujalte I, Passagne I, Brouillaud B, Treguer M, Durand E, Ohayon-Courtes C, et al. Cytotoxicity and oxidative stress induced by different metallic nanoparticles on human kidney cells. Part Fibre Toxicol. 2011;8:10. https:// doi.org/10.1186/1743-8977-8-10.

161. Wang B, Feng WY, Wang TC, Jia G, Wang M, Shi JW, et al. Acute toxicity of nano- and micro-scale zinc powder in healthy adult mice. Toxicol Lett. 2006; 161:115-23. https://doi.org/10.1016/j.toxlet.2005.08.007.

162. Wang C, Lu J, Zhou L, Li J, Xu J, Li W, et al. Effects of long-term exposure to zinc oxide nanoparticles on development, zinc metabolism and biodistribution of minerals ( $\mathrm{Zn}, \mathrm{Fe}, \mathrm{Cu}, \mathrm{Mn}$ ) in mice. PLoS One. 2016;11. https://doi.org/10.1371/journal.pone.0164434.

163. Najafzadeh H, Ghoreishi SM, Mohammadian B, Rahimi E, Afzalzadeh MR, Kazemivarnamkhasti $M$, et al. Serum biochemical and histopathological changes in liver and kidney in lambs after zinc oxide nanoparticles administration. Vet World. 2013;6. https://doi.org/ 10.5455/vetworld.2013.534-537.

164. Tang HQ, Xu M, Rong Q, Jin RW, Liu QJ, Li YL. The effect of ZnO nanoparticles on liver function in rats. Int J Nanomedicine. 2016. https://doi. org/10.2147/IJN.S109031

165. Saman S, Moradhaseli S, Shokouhian A, Ghorbani M. Histopathological effects of $\mathrm{ZnO}$ nanoparticles on liver and heart tissues in Wistar rats. Adv Biores. 2013;4(2):83-8.

166. Burns AA, Vider J, Ow H, Here E, Oula PM, Baumgart M, et al. Fluorescent silica nanoparticles with efficient urinary excretion for nanomedicine. Nano Lett. 2009;9:442-8. https://doi.org/10.1021/nl803405h.
167. Kumar R, Roy I, Ohulchanskky TY, Vathy LA, Bergey EJ, Sajjad M, et al. In vivo biodistribution and clearance studies using multimodal organically modified silica nanoparticles. ACS Nano. 2010;4:699-708. https://doi.org/10.1021/ nn901146y.

168. Wahab R, Kaushik N, Khan F, Kaushik NK, Choi EH, Musarrat J, et al. Selfstyled $\mathrm{ZnO}$ nanostructures promotes the cancer cell damage and supresses the epithelial phenotype of glioblastoma. Sci Rep. 2016. https://doi.org/10. 1038/srep19950.

169. Luo M, Shen C, Feltis BN, Martin LL, Hughes AE, Wright PFA, et al. Reducing ZnO nanoparticle cytotoxicity by surface modification. Nanoscale. 2014. https://doi.org/10.1039/c4nr00458b.

170. Chia SL, Leong DT. Reducing ZnO nanoparticles toxicity through silica coating. Heliyon. 2016. https://doi.org/10.1016/j.heliyon.2016.e00177.

171. Ramasamy M, Das M, An SSA, Yi DK. Role of surface modification in zinc oxide nanoparticles and its toxicity assessment toward human dermal fibroblast cells. Int J Nanomedicine. 2014. https://doi.org/10.2147/IJN.S65086.

172. Yung MMN, Fougères $P A$, Leung $Y H$, Liu F, Djurišić $A B$, Giesy JP, et al. Physicochemical characteristics and toxicity of surface-modified zinc oxide nanoparticles to freshwater and marine microalgae. Sci Rep. 2017. https:// doi.org/10.1038/s41598-017-15988-0.

173. Onnainty R, Onida B, Páez P, Longhi M, Barresi A, Granero G. Targeted chitosan-based bionanocomposites for controlled oral mucosal delivery of chlorhexidine. Int J Pharm. 2016. https://doi.org/ 10.1016/j.ijpharm.2016.06.011.

174. Martinez CR, Joshi P, Vera JL, Ramirez-Vick JE, Perales O, Singh SP. Cytotoxic studies of PEG functionalized ZnO nanoparticles on MCF-7 cancer cells. NSTI Nanotechnol. Conf. Expo, NSTI-nanotech; 2011.

\section{Ready to submit your research? Choose BMC and benefit from:}

- fast, convenient online submission

- thorough peer review by experienced researchers in your field

- rapid publication on acceptance

- support for research data, including large and complex data types

- gold Open Access which fosters wider collaboration and increased citations

- maximum visibility for your research: over $100 \mathrm{M}$ website views per year

At $\mathrm{BMC}$, research is always in progress.

Learn more biomedcentral.com/submissions 